\title{
Maternal antibodies: clinical significance, mechanism of interference with immune responses, and possible vaccination strategies
}

\author{
Stefan Niewiesk* \\ Department of Veterinary Biosciences, The Ohio State University, Columbus, OH, USA
}

\section{Edited by:}

Arnaud Marchant, Université Libre de Bruxelles, Belgium

Reviewed by:

Beate Kampmann, Imperial College London, UK

Hayley Gans, Stanford University

Medical Center, USA

${ }^{*}$ Correspondence:

Stefan Niewiesk, Department of Veterinary Biosciences, The Ohio

State University, 1925 Coffey Road,

Columbus, $\mathrm{OH} 43210$, USA

e-mail:niewiesk.1@osu.edu
Neonates have an immature immune system, which cannot adequately protect against infectious diseases. Early in life, immune protection is accomplished by maternal antibodies transferred from mother to offspring. However, decaying maternal antibodies inhibit vaccination as is exemplified by the inhibition of seroconversion after measles vaccination. This phenomenon has been described in both human and veterinary medicine and is independent of the type of vaccine being used. This review will discuss the use of animal models for vaccine research. I will review clinical solutions for inhibition of vaccination by maternal antibodies, and the testing and development of potentially effective vaccines. These are based on new mechanistic insight about the inhibitory mechanism of maternal antibodies. Maternal antibodies inhibit the generation of antibodies whereas the T cell response is usually unaffected. B cell inhibition is mediated through a cross-link between B cell receptor (BCR) with the Fcy-receptor IIB by a vaccine-antibody complex. In animal experiments, this inhibition can be partially overcome by injection of a vaccine-specific monoclonal lgM antibody. IgM stimulates the B cell directly through cross-linking the BCR via complement protein $\mathrm{C} 3 \mathrm{~d}$ and antigen to the complement receptor 2 (CR2) signaling complex. In addition, it was shown that interferon alpha binds to the CD21 chain of CR2 as well as the interferon receptor and that this dual receptor usage drives $B$ cell responses in the presence of maternal antibodies. In lieu of immunizing the infant, the concept of maternal immunization as a strategy to protect neonates has been proposed. This approach would still not solve the question of how to immunize in the presence of maternal antibodies but would defer the time of infection to an age where infection might not have such a detrimental outcome as in neonates. I will review successful examples and potential challenges of implementing this concept.

Keywords: maternal antibody, cotton rat, Fc $\gamma$ RIIB, B cell receptor, maternal immunization

\section{INTRODUCTION}

Vaccination of neonates and infants is problematic because of two unsolved problems: the immature immune system of neonates and the presence of inhibitory maternal antibodies. A number of studies have determined that the immaturity of the immune system is most pronounced after birth and is overcome as the child develops. The immaturity (inability to fully respond to an antigenic stimulus) of the neonatal immune system has been observed in humans (1) and a number of other species, e.g., pig (2), cow $(3,4)$, and horse (5), and in experimental rodent models like mouse (1), rat $(6)$, and cotton rat $(7,8)$.

Maternal antibodies are transferred from mother to child and protect neonates and infants during the time of maturation of their immune system. The vast majority of maternal antibodies are of the IgG isotype. In humans, maternal antibodies are preferentially transferred before birth transplacentally, and in animals of veterinary importance, preferentially through uptake of $\operatorname{IgG}$ in the intestine from colostrum within the first $24 \mathrm{~h}$ after birth. These passively acquired antibodies enter the bloodstream of offspring and act as a protective shield throughout the body in the same way as actively produced antibodies. Sometimes IgA antibodies contained in breast milk are also referred to as maternal antibodies. However, there are important differences in the action of passively transferred IgG and IgA antibodies. Upon transfer after birth, IgG antibodies are present in the bloodstream of the neonate in a finite amount that declines over time. These IgG antibodies suppress vaccine-induced immune responses. In contrast, IgA antibodies are continuously supplied through breast milk from the mother and protect the gastro-intestinal tract against pathogens without having an effect on the immune response. For the purpose of this review, the term "maternal antibodies" will be used for passively transferred IgG antibodies.

Maternal antibodies are very effective in protecting neonates and infants against most infectious diseases. The most impressive example is the protection of children with agammaglobulinemia (deficiency in the production of antibody) against bacterial infection for up to 6 months (9). Other documented examples of the ability of maternal antibodies to fully or partially protect are the amelioration of infection with respiratory syncytial virus (RSV) (10) or influenza virus (11) in humans, canine distemper virus in 
dogs (12), and infection with avian leukosis virus in chickens (13). Over time, maternal antibody titers decline because antibodies are being metabolized and do not protect any longer. However, even low, non-protective titers of maternal antibodies are still able to inhibit vaccination against infectious diseases of humans and animals. It is this phase of decaying maternal antibodies that presents a window of opportunity for infection by pathogens encountering the neonatal child or animal.

\section{INHIBITION OF VACCINATION BY MATERNAL ANTIBODIES}

In humans, maternal antibodies wane over a period of 612 months (14-17). The kinetics of maternal antibody decline is correlated to the amount of maternal antibody present in the neonate after birth in that higher titers persist for a longer time. In contrast to humans, the duration of maternal antibodies in agriculturally important animal species is usually 3-6 months (18-20) and in chicken only 4-7 days (21). In contrast, maternal antibodies in bats persist similar to humans for 6-12 months (22-24). Maternal antibodies in all species have been reported to reduce or abolish antibody generation after vaccination. The reduction or lack of antibody typically results in reduced or absence of protection against disease (Tables $\mathbf{1}$ and 2). It is of interest to note that all types of vaccines (live-attenuated, inactivated, subunit, and experimental vaccines) have been reported to be inhibited. For a number of experimental vaccines immunization with variable success in the presence of maternal antibodies has been reported but these reports have to be evaluated based on criteria set out in Section "Evaluation and Development of Experimental Vaccines."

\section{EXAMPLE: INHIBITION OF MEASLES VACCINATION BY MATERNAL ANTIBODIES}

The best studied example in human and veterinary medicine for the inhibition of vaccination by maternal antibody is measles vaccination. The measles vaccine virus (Edmonston strain) was developed in the late 1950s and early 1960s by attenuating a wild type virus on human and chicken embryo fibroblasts [for review see Ref. (62)]. Today various derivatives of the Edmonston strain are used as vaccine viruses worldwide (63). Immunization by both the standard subcutaneous and more experimental respiratory routes has been successful in protecting seronegative children (64). The protective immune response induced by vaccination consists of neutralizing antibodies against the two glycoproteins, with the (receptor-binding) hemagglutinin protein being the major target and the fusion protein the minor one (65). In addition, CD4 as well as CD8 $\mathrm{T}$ cell responses are induced. Case reports describing persistent MV infection in T cell deficient patients support the notion that $\mathrm{T}$ cells are required to clear infection but do not protect against infection (66). This role of CD8 T cells in virus clearance has been confirmed in the Rhesus macaques model (67). In cotton rats, CD4 $\mathrm{T}$ cells have no role in protecting or clearing virus from the respiratory tract (68). However, in mice they have a role in clearing virus infection from brain tissue through production of $\operatorname{IFN} \gamma(69,70)$.

During their first year of life, children are protected by neutralizing maternal antibodies against MV infection. Over time, these antibody titers wane and eventually do not protect against
Table 1 | Inhibition of seroconversion of human vaccines by maternal antibodies.

\begin{tabular}{llc}
\hline Infectious agent & Type of vaccine & Reference \\
\hline Tetanus & Combination protein vaccine & $(25)$ \\
Pneumococcus & Combination protein vaccine & $(25,26)$ \\
Hib & Combination protein vaccine & $(25,27)$ \\
Pertussis & Combination protein vaccine & $(25)$ \\
Measles virus & Acellular and whole-cell vaccine & $(28)$ \\
Mumps virus & Live-attenuated & $(29-31)$ \\
Hepatitis A virus & Live-attenuated & $(32)$ \\
Hepatitis B virus & Inactivated virus & $(33)$ \\
Rotavirus & Protein vaccine & $(34)$ \\
Poliovirus & Live-attenuated & $(35)$ \\
Influenza virus & Inactivated virus & $(36,37)$ \\
& Live-attenuated vaccine & $(38)$ \\
\hline
\end{tabular}

This table lists examples of studies, which document the inhibition of or reduction in seroconversion after immunization with both live and non-live vaccines. Jones et al. (25) document a stronger inhibitory effect of maternal antibodies on tetanus and pneumococcal vaccines than Hib and pertussis vaccines. Most studies indicate that higher levels of maternal antibodies inhibit antibody development more severely than low titers. Two studies $(29,35)$ indicate that an increase in dose helps to improve antibody responses after immunization in the presence of maternal antibodies.

wild type infection [for review see Ref. (71)]. Even these low, non-protective antibody titers inhibit seroconversion after both subcutaneous and intranasal immunization in cotton rats as well as humans. The lack of seroconversion severely reduces protection after vaccination with the live-attenuated vaccine virus. In the cotton rat model, this leads to a complete lack of protection (68). In clinical studies, immunization in the presence of maternal antibodies leads to partial reduction in mortality (72) and morbidity (73) (even in seronegative children). However, a broad clinically desirable protective immunity (protective $\mathrm{T}$ and $\mathrm{B}$ cell responses, and no clinical symptoms after infection rather then reduction in morbidity and mortality) is not established after immunization in the presence of maternal antibodies.

In contrast to the antibody response, $\mathrm{MV}$-specific $\mathrm{T}$ cell proliferation is usually measurable after immunization in the presence of maternal antibodies (74-76). In spite of the inhibition of seroconversion, it was observed that vaccination in the presence of maternal antibodies leads to priming of B cells. Although no antibodies were produced, children immunized with measles vaccine in the presence of maternal antibodies responded with a higher immune response to booster vaccination after maternal antibodies had declined than children who had not been vaccinated at all (77). This study indicated that inhibition of B cell responses by maternal antibodies is a temporary effect and not due to the induction of anergy. However, it has also been observed that in children who were immunized in the presence of maternal antibodies long term 
Table 2 | Inhibition of seroconversion of veterinary vaccines by maternal antibodies.

\begin{tabular}{|c|c|c|c|}
\hline Species & Infectious disease & Type of vaccine & Reference \\
\hline \multirow[t]{2}{*}{ Dog } & Canine parvovirus & Live-attenuated & $(40,41)$ \\
\hline & Canine distemper virus & Live-attenuated & $(42,43)$ \\
\hline \multirow[t]{3}{*}{ Cat } & $\begin{array}{l}\text { Feline panleukopenia } \\
\text { virus }\end{array}$ & Live-attenuated & $(44,45)$ \\
\hline & Feline herpesvirus 1 & Inactivated virus & $(44)$ \\
\hline & Feline calicivirus & Inactivated virus & $(44)$ \\
\hline \multirow[t]{3}{*}{ Cow } & $\begin{array}{l}\text { Bovine viral diarrhea } \\
\text { virus }\end{array}$ & Live-attenuated & $(46,47)$ \\
\hline & $\begin{array}{l}\text { Foot and mouth } \\
\text { disease virus }\end{array}$ & Inactivated virus & $(48)$ \\
\hline & $\begin{array}{l}\text { Bovine respiratory } \\
\text { syncytial virus }\end{array}$ & Live-attenuated & $(49-51)$ \\
\hline \multirow[t]{5}{*}{ Pig } & $\begin{array}{l}\text { Erysipelothrix } \\
\text { rhusiopathiae }\end{array}$ & Live-attenuated & (52) \\
\hline & Pseudorabies virus & Genetically attenuated & (53) \\
\hline & $\begin{array}{l}\text { Classical swine fever } \\
\text { virus }\end{array}$ & Protein vaccine & $(54,55)$ \\
\hline & & Live-attenuated & \\
\hline & Influenza virus & Protein vaccine & $(56)$ \\
\hline Chicken & Influenza virus & Inactivated virus & (57) \\
\hline \multirow[t]{2}{*}{ Raccoon } & Rabies virus & $\begin{array}{l}\text { Vaccinia virus expressing } \\
\text { rabies glycoprotein }\end{array}$ & (58) \\
\hline & Canine distemper virus & Live-attenuated & (59) \\
\hline Wolves & Canine distemper virus & Live-attenuated & (60) \\
\hline Ferrets & Canine distemper virus & Live-attenuated & (61) \\
\hline
\end{tabular}

This table lists examples of studies, which document the inhibition of or reduction in seroconversion after immunization with both live and non-live vaccines in different species. It also lists an example of a vaccine lagainst canine distemper virus), which is inhibited in several species. Three studies $(46,51,53)$, included in their study $T$ cell measurements and detected $T$ cell responses after immunization in the presence of maternal antibodies although the antibody response was inhibited.

antibody titers were reduced (even after boosting) compared to children who were seronegative at the time of immunization (76).

Since no current vaccine formulation is fully effective in the presence of maternal antibodies, two approaches have been used clinically to address the problem: one, the use of a high titer vaccine, and the other, the determination of the earliest time point possible for successful vaccination. The high titer vaccine $\left(>10^{4.7} \mathrm{pfu}\right.$ ) had a 10 - to 50 -fold higher viral titer than the normal vaccine and induced some level of protection after immunization in the presence of maternal antibodies $(29,78)$. However, the use of this vaccine was associated with increased mortality (particularly in females) (79-81), which was attributed to immune suppression by the vaccine and its use was discontinued. A possible explanation for higher mortality in girls might be that girls have been reported to have lower maternal antibody titers (82) that were overwhelmed by a higher vaccine virus dose.
In a second approach, children were immunized at different times after birth (in the face of declining maternal antibodies). These studies have shown that a low level of maternal antibody correlates best with vaccination success. At the age of 6 months, maternal antibody titers are still high enough to suppress seroconversion but at the age of 9 months vaccination campaigns are relatively successful $(31,83)$. However, the complete disappearance of antibody at the age of 12 months seems to be optimal for immunization $(32,74,84-86)$. Additional studies into the levels of maternal antibodies demonstrated that strong regional differences exist in that in a number of countries maternal antibodies might have disappeared by 6 months of age, and sometimes immunization at 4.5 months of age might be partially successful $(87,88)$. Regional differences might be due to a number of factors such as the exposure to wild type virus infection of mothers, which results in higher antibody titers and higher transfer rates into children than in vaccinated mothers (89). Maternal antibody levels in children of vaccinated mothers are lower and decline earlier than in children from naturally infected mothers.

\section{CLINICAL RELEVANCE OF INHIBITION OF VACCINATION BY MATERNAL ANTIBODIES AND PRACTICAL SOLUTIONS}

Numerous reports detail the inhibition of antibody responses after vaccination in the presence of maternal antibodies. The important question is whether this is clinically relevant and whether clinical solutions exist to overcome the problem. For measles virus vaccination, maternal antibodies clearly inhibit the generation of neutralizing antibodies and therefore severely restrict protective immunity. However, the clinical outcome might vary depending on the specific vaccine and infectious disease under study. A recent study found that suppression of antibody responses against the tetanus and pneumococcal vaccines was more pronounced than against hemophilus influenza $B$ and pertussis vaccines (25). Theoretically, immunization should be successful when maternal antibodies have declined below the threshold of detection. In practice, it is not feasible to accurately predict this time point as it depends on the amount of maternal antibody transferred, region, gender, nutritional status, and species. Therefore, the measurement of antibody levels would be required before immunization, which is not feasible in a clinical setting. The clinical practice to immunize children and animals repeatedly because most immunizations are based on a prime-boost principle, also ensures that children and animals are immunized when maternal antibodies have been metabolized. Immunization in the presence of maternal antibodies does not interfere with later vaccinations, and this practice ensures that eventually the individual is immunized when maternal antibodies have disappeared. However, a variable period of time without active immune protection will remain and therefore this vaccination schedule is most successful in regions with a low prevalence of infection. The other important question for vaccination is whether antibodies or $\mathrm{T}$ cells are a correlate of protection. If $\mathrm{T}$ cells play a major role in protection [e.g., Aujeszky virus (90)], early immunization will afford protection because the $\mathrm{T}$ cell response is affected very litthe by maternal antibodies. If, in contrast, neutralizing antibodies are required for protection, early immunization is not likely to succeed. 


\section{TYPE OF PLACENTA DETERMINES MODE OF TRANSFER OF MATERNAL ANTIBODIES}

The transfer of maternal antibodies from mother to offspring may occur during pregnancy (from the maternal blood via transplacental transfer) and within $24 \mathrm{~h}$ after birth (from colostrum via the small intestine). The amount of antibody transferred by these two mechanisms differs by species depending on the type of placenta (http://placentation.ucsd.edu/placenta.html). Just prior to formation of the placenta, there are a total of six layers of tissue separating maternal and fetal blood. There are three layers of fetal extraembryonic membranes in the chorioallantoic placenta of all mammals, all of which are components of the mature placenta: endothelium lining allantoic capillaries, connective tissue in the form of chorioallantoic mesoderm, and the chorionic epithelium, the outermost layer of fetal membranes derived from trophoblasts. There are also three layers on the maternal side, but the number of these layers that are retained - that is, not destroyed in the process of placentation - varies greatly among species (see Table 3 ). Overall, species with few layers between maternal and fetal blood have a higher rate of transport of maternal antibodies transplacentally [through Fc-receptors $(\mathrm{FcR})$ ]. In species with more layers between maternal and fetal blood, the transport of maternal antibodies preferentially occurs through colostrum. Although the differences between species are important for the study of placentation and transfer of nutrients, for the study of vaccination in the presence of maternal antibodies the structure of the placenta and the mode of transmission of IgG is only relevant if intrapartum studies are performed. Most studies, however, assess the inhibition of vaccination sometime after birth and the relevant parameter in these experimental settings is the amount of IgG being transferred to the offspring.

\section{EXPERIMENTAL MODELS TO STUDY THE EFFECT OF HOMOLOGOUS VERSUS HETEROLOGOUS PASSIVELY TRANSFERRED ANTIBODIES ON VACCINATION}

Inhibition of vaccination has been studied in the presence of natural maternal antibodies or in the presence of passively transferred homologous or heterologous antibodies. Overall, inhibition of seroconversion after vaccination has been similar using both methods. For the induction of natural maternal antibodies, dams are immunized during pairing with the male and will transfer maternal antibodies to the pups. In rodents, differences can be found in antibody levels between pups of the same litter, which may occur because of the suckling hierarchy. The supposed advantage of natural maternal antibodies is the fact that antibodies from the same species have a predetermined fit for the FcR present in the

Table 3 | Type of placenta is species specific and determines route of transfer of maternal antibodies.

\begin{tabular}{|c|c|c|c|c|}
\hline Species & Placenta & $\begin{array}{l}\text { Maternal antibody } \\
\text { transfer }\end{array}$ & $\begin{array}{l}\text { Transfer mediated by } \\
\text { neonatal Fc receptor (FcRn) }\end{array}$ & Reference \\
\hline Human & Hemochorial & Transplacental & $\begin{array}{l}\text { Yes; preferential transport of } \\
\lg \mathrm{l} 1>\lg G 3>\lg G 4>\lg G 2\end{array}$ & $(91-94)$ \\
\hline $\begin{array}{l}\text { Rodents } \\
\text { Mouse } \\
\text { Rat }\end{array}$ & Hemochorial & Transplacental/colostrum & Yes & $(6,95-98)$ \\
\hline Cotton rat & Hemochorial & Transplacental/colostrum & Unknown & $(99,100)$ \\
\hline Dogs and cats & Endotheliochorial & $\begin{array}{l}\text { Low transplacental/high } \\
\text { in colostrum }\end{array}$ & Unknown & $(12,20,40,101-104)$ \\
\hline $\begin{array}{l}\text { Cattle, sheep, } \\
\text { pigs, and horses }\end{array}$ & Epitheliochorial & Colostrum & $\begin{array}{l}\text { FcRn present in pig intestine, } \\
\text { role in IgG transfer questionable }\end{array}$ & $(94,105-107)$ \\
\hline Birds & None & In ovo & FcRY (bird equivalent to FcRn) & $(108,109)$ \\
\hline
\end{tabular}

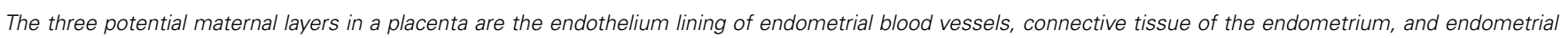

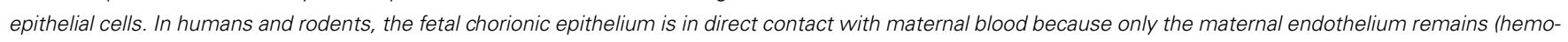

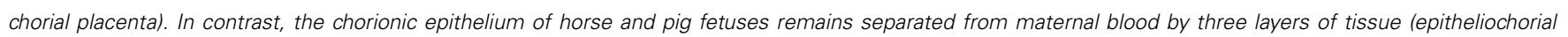

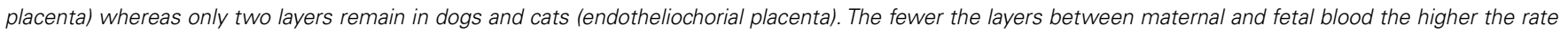

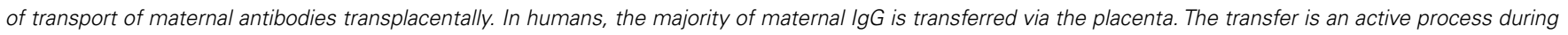

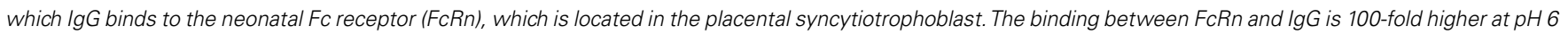

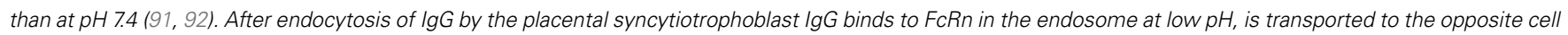

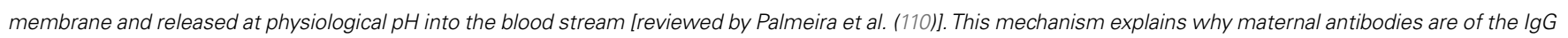

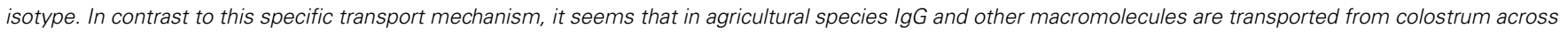
the intestinal barrier in a non-specific fashion (111, 112). Within 24-h after birth, the intestine becomes impermeable to macromolecules and lgG transfer ceases.

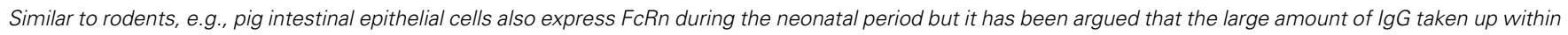

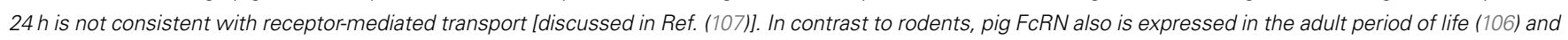

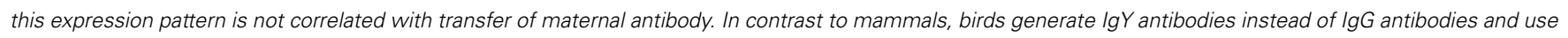
the IgY Fc-receptor (FCRY) to transport lgY into the egg. 
species whereas heterologous IgG does not always interact with FcR $(113,114)$. However, studies in mice and humans have shown that subclasses of homologous IgG differ in their interaction with FcR $(115,116)$.

Often, the question of inhibition of vaccination by maternal antibodies will have to be separated from the immaturity of the neonatal immune system experimentally. One possible resolution is the transfer of homologous immune serum into adolescent animals (117). Using this experimental model, it was shown that suppression of vaccine responses correlates with amount of antibody present at the time of immunization (118). The injection of antibodies allows us to determine the amount of antibody transferred and ensures equal titers in all animals of the experimental group. In addition, often higher titers of passively transferred antibody can be achieved than would be possible through the induction of natural maternal antibodies. A disadvantage of homologous antibodies (whether natural maternal antibodies or passively transferred) is that they are indistinguishable from antibodies induced actively via immunization. The transfer of heterologous antibodies provides the advantage that actively induced and passively transferred antibodies can be distinguished by ELISA. Heterologous antibodies degrade faster than homologous antibodies, and e.g., in the cotton rat model the half-life of cotton rat IgG was estimated to be 7 days versus a half-life of 3.5 days for injected human IgG (Niewiesk, unpublished). The rate of decay should not matter for vaccination studies, as the amount of antibody at the time of vaccination is important for inhibition, not the duration of antibody levels. However, one should not inject heterologous antibodies repeatedly, as that will lead to the induction of regulatory $\mathrm{T}$ cells, which might interfere with the immune response after vaccination (119). Another caveat is warranted when monoclonal antibodies are used. It is important to test whether specific subclasses will interact with the Fc $\gamma$ RIIB receptor in the respective species and be able to suppress $\mathrm{B}$ cell responses. In cotton rats, for example, mouse IgG1 antibodies do not bind to the Fc $\gamma$ IIB receptor and do not interfere with vaccination whereas mouse IgG2a antibodies do (114).

\section{MECHANISMS OF INHIBITION OF VACCINATION BY MATERNAL ANTIBODIES \\ ANTIBODY FEEDBACK MECHANISM}

Since studies to address the mechanism of inhibition of seroconversion after vaccination in the presence of maternal antibodies have been rare, data from antibody feedback regulation have been used to provide mechanistic insight into B cell inhibition by antibody. Antibody feedback regulation is the phenomenon whereby co-injection of an antigen [usually sheep red blood cells (SRBC)] and monoclonal antibody specific for this particular antigen into a naive mouse leads to a reduction or inhibition in the generation of antigen-specific antibodies. [It is important to note that this phenomenon is true for large particulate antigens like SRBC and keyhole limpet hemocyanin (KLH)]. The suppression increases with the amount and affinity of antibody given $(120,121)$ but is independent of the IgG isotype $(120,121)$. In contrast to the B cell response, a $\mathrm{T}$ helper cell response is not inhibited (122). Moreover, a recall response can be induced after the decline of passively transferred antibody. Two major hypotheses might explain this phenomenon: epitope masking and B cell regulation through the Fc $\gamma$-receptor IIB (Fc $\gamma$ RIIB).

\section{Inhibition of B cell responses through epitope masking}

Sheep red blood cell-specific antibodies recognize very few highly repetitive epitopes on SRBC. The theory of epitope masking postulates that antibodies can cover these epitopes and mask them from B cell recognition if enough antibody is used. Originally, it was thought that all epitopes have to be covered by antibodies to prohibit recognition by B cells (epitope-specific suppression). However, it was shown that a monoclonal antibody against one epitope can suppress recognition of a whole particulate antigen by $B$ cells (epitope unspecific suppression) $(120,121,123)$. It has been argued that at high antibody concentrations, steric hindrance might explain this form of suppression. But even low antibody concentrations of $0.4 \mu \mathrm{g}$ (corresponding to $2 \times 10^{6}$ antibody molecules) are able to suppress antibody responses against $10^{8}$ SRBC (124). Epitope masking as a mechanism of suppression has always been discussed in conjunction with a competing mechanism, the regulation of B cells through the Fc $\gamma$ RIIB.

\section{Inhibition of B cell responses by binding of IgG to the Fcy-receptor IIB}

$\mathrm{B}$ cells express the Fc $\gamma \mathrm{RIIB}$ as the only $\mathrm{Fc} \gamma$ receptor on their surface. It has been shown in vitro that IgG specific for the $\mathrm{B}$ cell receptor (BCR) binds to the $\mathrm{BCR}$ via its antigen binding domain in the variable region and to Fc $\gamma$ RIIB through the constant region. Through the cross-linkage between BCR and Fc $\gamma$ RIIB, the tyrosine-based inhibitory motif of Fc $\gamma$ RIIB is in close proximity to the tyrosine-based activation motif of the BCR. This proximity leads to inhibition of antigen-specific $\mathrm{B}$ cell activation. In vitro, SRBC-specific B cells from spleens of immunized mice can be activated by addition of SRBC to secrete antibody, which can be detected using an ELISPOT system. This activation can be inhibited by the addition of SRBC-specific IgG (124), which forms a complex with SBRC and links the BCR to Fc $\gamma$ RIIB. In contrast, the $\mathrm{F}\left(\mathrm{ab}^{\prime}\right)_{2}$ fragment, which lacks the constant region $(\mathrm{Fc})$ of $\mathrm{IgG}$, cannot cross-link these receptors and inhibit B cell stimulation. Similarly, mouse B cells with a deletion in the gene coding for the $\gamma$ chain of the Fc $\gamma$ RIIB cannot be inhibited by SRBC-specific IgG (124). These in vitro data strongly argue for a role of Fc $\gamma$ RIIB in down-regulating B cell responses. In contrast, data obtained in vivo do not unequivocally support the ability of IgG to suppress B cell responses by $\mathrm{Fc} \gamma \mathrm{RIIB}$ binding. In support of this mechanism are data demonstrating that glycosylation of the constant region $(\mathrm{Fc})$, which is crucial for binding of IgG to the inhibitory Fc $\gamma$ RIIB, is necessary for inhibition $(125,126)$. In addition, some studies have shown that $\mathrm{F}\left(\mathrm{ab}^{\prime}\right)_{2}$ fragments, in contrast to complete IgG, do not inhibit antigen-specific responses $(120,127,128)$. However, other studies found little difference between $\mathrm{F}\left(\mathrm{ab}^{\prime}\right)_{2}$ fragments and complete IgG $(120,127,128)$, and in mice with a genetically deleted Fc $\gamma$ RIIB (and also deletion of Fc $\gamma$ RI and Fc $\gamma$ RIII) inhibition still could be induced by IgG (124). Two technical comments must be made in regard to the latter studies. After pepsin digestion, the quality of the $\mathrm{F}\left(\mathrm{ab}^{\prime}\right)_{2}$ fragments varies and was not rigorously controlled in these studies. In the study using genetically modified mice, the deletion of the common $\gamma$-chain $(\mathrm{FcR} \gamma)$ leads to 
the absence of Fc $\gamma$ RI, Fc $\gamma$ RIIB, and Fc $\gamma$ RIII. In consequence, these mice displayed a wide array of immunological abnormalities that were not restricted to the B cell compartment (124). After antigen injection, these mice generated a markedly stronger antibody response indicating the lack of a feedback mechanism to regulate $\mathrm{B}$ cell responses and antibody titers.

\section{Stimulation of $B$ cell responses by the binding of IgM to the CD21/CD19/CD81/Leu-13 signaling complex}

In the study of antibody feedback regulation, it was found that co-injection of antigen and antigen-specific IgM increases antibody responses in the presence of an inhibitory $\operatorname{IgG}(125)$. These data suggest that the inhibitory signal through Fc $\gamma$ RIIB can be overcome by stimulating signals via the complement receptor 2 (CR2) (CD21/CD19/CD81/Leu-13) complex. In vitro, a complex of antigen, IgM and complement protein C3d cross-links the BCR and CR2 and leads to B cell activation $(129,130)$. C3d which binds to CD21 is produced through the activation of the classical complement pathway involving the $\mathrm{C} 2$ and $\mathrm{C} 4$ complement proteins. In mice, the cross-linkage increases the responsiveness of $\mathrm{B}$ cells in the presence of antigen-specific IgM and antigen by two orders of magnitude in comparison to antigen alone (131). This immune enhancement by IgM is not seen in CD21 gene-targeted mice (132) or mice in which complement was depleted prior to vaccination (125) or in the absence of antigen. These data support a regulatory role of IgG on B cell activation that can be overcome by stimulation through IgM, and argues against simple epitope masking.

\section{MECHANISM OF INHIBITION OF SEROCONVERSION AFTER VACCINATION IN THE PRESENCE OF MATERNAL ANTIBODIES}

In addition to mechanisms based on the work performed in the antibody feedback mechanism model (epitope masking and B cell inhibition through Fc $\gamma$ RIIB), two additional mechanisms have been hypothesized to play a role in inhibition of vaccination by maternal antibodies: removal of vaccine antigen by macrophages and neutralization of vaccine virus by maternal antibodies.

\section{Antigen removal by macrophages}

It has been assumed that macrophages remove antibody-virus complexes from the circulation through binding to FcR to such a degree as to abolish immune responses. There is no experimental evidence to support this hypothesis, and it also does not explain why the $\mathrm{B}$ cell response is preferentially inhibited whereas a $\mathrm{T}$ cell response is consistently detected after immunization in the presence of maternal antibodies. The only evidence that Fcreceptor-mediated phagocytosis of antigen-antibody complexes redirects the immune response is the finding in mice that it leads to increased IL10 secretion (133). The increase in IL10 could direct $\mathrm{T}$ cell responses toward a Th2 response, which, however, would not lead to a decrease in antibody responses. So far, there has been no evidence that the removal of antigen-antibody complexes by macrophages influences antibody responses.

\section{Neutralization of live-attenuated vaccine}

An often-suggested explanation for the lack of vaccination success in the presence of maternal antibodies is neutralization of the vaccine virus, which would reduce the amount of viral antigen below a certain (undefined) threshold and thereby interfere with immune recognition. Three facts argue against this hypothesis: maternal antibodies suppress not only replicating live-attenuated vaccines but also (non-replicating) protein vaccines; immunization with vector systems expressing measles virus proteins (which are not sensitive to neutralizing antibodies) are inhibited by maternal antibodies (134-136); and non-neutralizing antibodies block vaccination with a live-attenuated vaccine (114).

\section{B cell inhibition through epitope masking}

The idea of epitope masking predicts that $\mathrm{B}$ cell epitopes on a vaccine will be covered by antibody and therefore will not be recognized by B cells. In consequence, this effect is dependent on the concentration of antibody present in the circulation, and should be seen with both a complete IgG antibody and an IgG antibody lacking its constant region [so-called $\mathrm{F}(\mathrm{ab})_{2}$ fragment]. However, experimentally we could demonstrate that one antibody at a high concentration is less efficient in inhibiting vaccination than three antibodies at lower concentrations, and that only complete IgG antibody can block vaccination (114). In addition, the inhibition of antibody generation afterward was not specific to the epitope recognized by the inhibitory antibody.

\section{B cell inhibition through cross-link of BCR with FcyRIIB}

In contrast to these results, which did not support epitope masking as a mechanism, the interaction between Fc $\gamma$ RIIB and maternal antibodies proved to be important. Both in vitro and in vivo, IgG can block $\mathrm{B}$ cell responses whereas $\mathrm{F}(\mathrm{ab})_{2}$ fragments cannot. A monoclonal antibody with an Fc region that does not bind to cotton rat Fc $\gamma$ RIIB cannot inhibit B cell responses (114). These data support a mechanism of inhibition depending on complex formation of the vaccine with IgG antibodies (114). This complex cross-links the BCR (which recognizes the vaccine antigen) to the FcyIIB receptor (which binds the Fc region of the IgG antibody) on the surface of B cells. The cross-link results in a negative signal that inhibits both the proliferation of B cells (137) and the secretion of antibodies (114) (Figure 1A). In evolutionary terms, this mechanism developed to avoid an over-reactive B cell response in order to conserve resources. If IgG antibodies are already present in an organism after infection or vaccination, it is not necessary to produce more antibodies. In essence, maternal antibodies signal that there is no need to produce more antibodies. In contrast to antibody production after an active immune response, however, the passively transferred maternal antibodies decline and the infant is left without an adequate B cell and antibody response.

\section{IgM stimulation of inhibited $B$ cells}

Further evidence in support of the regulatory model of B cell inhibition is provided by the role of IgM in the stimulation of B cells in vitro and in vivo. The negative feedback regulation of $\mathrm{B}$ cells should function in children with similar IgG titers irrespective of whether they have been actively immunized or have received maternal antibodies. However, immunized children will generate additional antibodies after re-immunization whereas children with maternal antibodies will not or at very low titers. This phenomenon can (at least partially) be explained by the presence of 

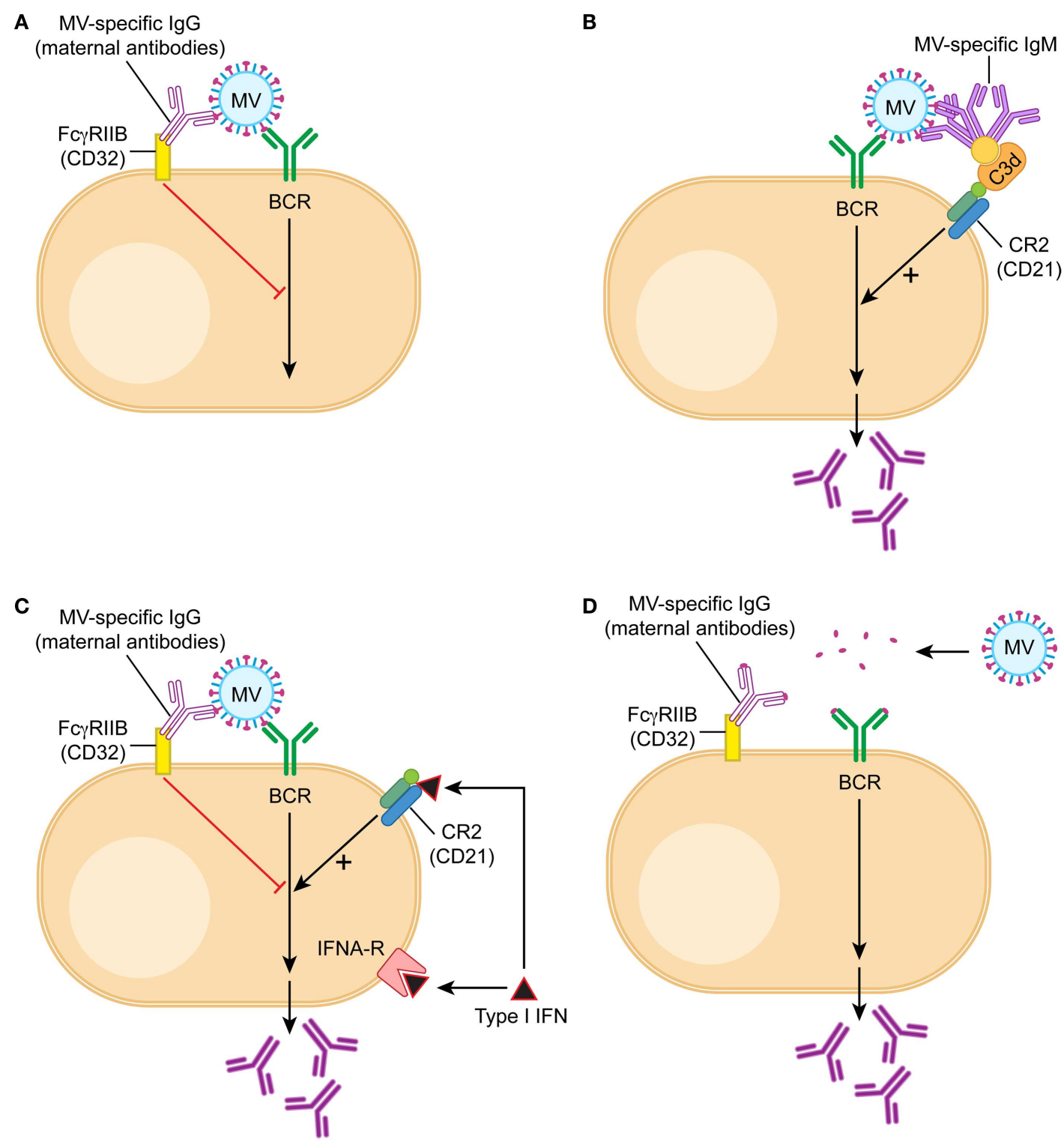

FIGURE 1 | Model of $B$ cell activation in the presence of maternal lgG $B$ cells are being stimulated through three signals, the first one is recognition of antigen by the $\mathrm{B}$ cell receptor (BCR), the second the interaction with $\mathrm{T}$ cells through CD40/CD40 ligand, and the third cytokines like type I interferon or IL-6. During vaccination in the presence of maternal antibodies T cell responses are generated and therefore the second signal is provided. (A) In the presence of maternal antibodies (lgG), the first signal is downregulated by a cross-link between BCR and Fc $\gamma R$ RIIB. If MV-specific IgG binds to MV, the constant region is bound by the receptor for the constant region $(\mathrm{FC})$ of $\lg \mathrm{G}$ (which is Fc $\gamma R$ RIIB). Fc $\gamma R$ RIIB is the only Fc-receptor on B cells and does not bind other immunoglobulins like $\operatorname{lgM}$ or $\lg A$. After juxtaposition of the $B C R$ and $F_{C} \gamma R \| B$, the tyrosine-based inhibitory motif of Fc $\gamma R$ RIIB is in close proximity to the tyrosine-based activation motif of BCR and delivers a negative signal. (B) If MV-specific IgM binds to MV, it also binds via $\mathrm{C} 3 \mathrm{~d}$ to CD21 (complement receptor 2), which is part of the positively signaling CD21/CD19/CD83/Leu-13 complex. The opsonin C3d does not bind to lgG. (C) Interferon $\alpha$ (type I interferon) binds to both the interferon receptor and CD21, and the dual receptor usage leads to a strong positive signal. It stimulates antibody secretion by B cells in the presence of maternal antibodies. (D) A possible approach to vaccination in the presence of maternal antibodies is the reduction of the vaccine antigen into small units, which do form antigen-antibody complexes unable to cross-link BCR and FcyRIIB. An example of this approach is experimental vaccination against respiratory syncytial virus in the presence of maternal antibodies (138).
IgM that is being generated after active immunization. IgM forms a complex with the vaccine and a complement protein $(\mathrm{C} 3 \mathrm{~d})$. This complex cross-links the BCR with the CR2 on the surface of B cells (Figure 1B). The cross-link results in activation of $\mathrm{B}$ cells in vitro and can partially overcome the inhibition by the cross-link of the
BCR and CD32 in vivo (114). In consequence, some IgG antibody is produced. The important component for the stimulatory effect of CR2 is the CD21 chain that binds to C3d. This finding is consistent with the model of $\mathrm{B}$ cell regulation but not with epitope masking. 


\section{Type I interferon induction stimulates B cells in the presence of maternal antibodies}

Another way to stimulate B cells experimentally in the presence of maternal antibody is the induction of type I interferon. It has been demonstrated that CD21 binds C3d and interferon alpha with the same affinity (139) indicating that interferon alpha might have a functional role in B cell stimulation. Indeed, interferon alpha stimulation leads to the up-regulation of a number of $\mathrm{B}$ cell genes in a human B cell line (140). In vivo, B cells use both the interferon receptor and CD21 (which is a chain of the CR2) as a functional interferon receptor to stimulate antibody secretion (137) (Figure 1C). One way of inducing high levels of type I interferon is the combined use of TLR-3 and TLR-9 agonists as adjuvants for immunization. Because of the dual receptor usage, the induction of type I interferon in vivo strongly stimulates $\mathrm{B}$ cell responses and restores antibody levels after immunization in the presence of maternal antibodies (137). This finding is consistent with the model of Fc $\gamma$ RIIB-mediated inhibition of B cell regulation but not with epitope masking.

In neonates, immunization is not only impaired by the inhibitory action of maternal antibodies, but also by the overall immaturity of the immune system. The induction of type I interferon stimulates immature B cells in neonatal cotton rats, even in the presence of maternal antibodies (141).

\section{Engagement of Fc $\gamma$ RIIB is important for inhibition of B cells}

Using the cotton rat model of measles virus vaccination (142), we have shown that maternal antibodies inhibit B cells through complex formation with the vaccine and cross-linking of the BCRs and Fc $\gamma$ RIIB (114). A mixture of antibodies recognizing three or more epitopes was more inhibitory than one antibody at the same antibody concentration. These data support the current thinking that oligomerization of Fc $\gamma$ RIIBs is required for an inhibitory signal interfering with B cell proliferation and antibody secretion (143). However, for effective oligomerization not only the number of different antibodies but also the size of an antigen seems to be important. Passively transferred antibodies specific for di-nitrophenyl (DNP) groups inhibit immunization with DNP bound to SRBC $(4-5 \mu \mathrm{m})$ but not immunization with DNP bound to KLH (two subunits of 30 and $33 \mathrm{~nm})(144,145)$. Similarly, measles virus, which is inhibited by maternal antibodies, is a large antigen [250-450 nm (146)] with multiple epitopes on its surface [at least 13 for hemagglutinin (MV-H) and 6 for fusion protein (MV-F)] (147). These data indicate that an antigen requires a certain size to effectively cross-link (as antibody-antigen-complex) BCRs and Fc $\gamma$ RIIBs (Figure 1D). Consistent with this concept is a report that immunization with a small polypeptide containing a neutralizing B cell epitope escaped inhibition by maternal antibodies (138).

\section{EVALUATION AND DEVELOPMENT OF EXPERIMENTAL VACCINES}

A number of studies claim vaccine efficacy after immunization in the presence of maternal antibodies for both approved vaccines and vaccine candidates. For experimental vaccines successes as well as failures have been reported for a variety of vector systems expressing the vaccine antigen simultaneously with or without different cytokine (combinations). The results from these studies are contradictory and it helps to clearly define the experimental conditions and study design. A vaccine can most easily be proven to be successful if it is used in the presence of low titers of maternal antibodies at the time of immunization, if $\mathrm{T}$ cell responses are measured and if surrogate markers like histological changes (in animal models) are used for protective efficacy. To prove convincingly vaccine efficacy in the presence of maternal antibodies, levels of maternal antibodies at the time of vaccination have to be high, neutralizing antibodies should be measured as an immunological parameter, and protection should be measured as clinical efficacy by the absence of clinical symptoms or a significant reduction in viral/bacterial titers. By these standards, very few examples of successful immunization in the presence of maternal antibodies exist, thus necessitating further research into this area. When considering the development and testing of vaccines for immunization in the presence of maternal antibodies, three options seem to emerge as being potentially successful: inoculation at a site with low IgG, continuous expression of antigen, and inoculation with adjuvants stimulating type I interferon secretion. Inhibitory maternal antibodies are of the IgG isotype, and IgG is present in respiratory and ocular fluids and saliva $(148,149)$ although at lower concentrations than in the blood. Occasionally, vector systems have been used successfully in animal model in the presence of maternal antibodies when alternate routes of immunization (other than subcutaneous or intramuscular) were used (134, 150-152). Experimentally, this approach could be combined with measures of IgG titers at the site of inoculation (e.g., mouth, eye, and nose) to correlate vaccination success with lower antibody titers. The concept of continuous expression of antigen is based on the finding that repeated immunization leads to an antibody response in the presence of maternal antibodies. If a vector system can be found that continuously expresses antigen, B cell responses should be stimulated when antibody titers fall to very low levels. An example of this concept is the expression of infectious bursitis virus (IBV) proteins through an attenuated Marek's diseases virus (MDV) vector that persists in the chicken and leads to good immunity (153) in the presence of maternal antibodies. The induction of type I interferon is based on the ability of type I interferon to drive $B$ cell responses in tissue culture and in experimental systems in the presence of maternal antibodies. An example of this concept is the immunization of pigs with adjuvants inducing type I interferon (154).

\section{INDUCTION OF MATERNAL ANTIBODIES THROUGH MATERNAL IMMUNIZATION AS INDIRECT IMIMUNIZATION OF INFANTS}

Because of their relative immunological immaturity, infants are usually not immunized before the age of 2-3 months (depending on country-specific immunization schedules) with the most common exception of neonatal BCG immunization in some countries. In order to provide protection earlier in life, two other vaccination strategies have been discussed and/or used: cocooning and maternal immunization. The method of cocooning relies on immunization of all people in contact with the infant to minimize the risk of pathogen transmission and infection. Although this method can be effective it is sometimes difficult to implement. Another concept that has received more attention recently is 
maternal immunization. Maternal antibodies have been proposed as a means of protecting the infant during a sensitive time in the development of their immune system. If protective high levels of maternal antibodies can be achieved in infants, they would be protected during the most immature phase of their immune system. In addition, the young organism becomes better adapted to cope with infectious diseases by improved non-immune host responses, e.g., faster regeneration of epithelial cells after gastro-intestinal infection. Maternal immunization has the added advantage that the mother's immune system is fully mature and will respond well to vaccination, thus providing protection to the mother and high levels of maternal antibodies to the infant. Based on the above named studies about protective levels of maternal antibodies and their kinetics of decline, it should theoretically be possible to induce high levels of antibodies, which are protective for up to 6 months.

\section{SUCCESSFUL EXAMPLES OF MATERNAL IMMUNIZATION}

Currently, this concept is supported by data for vaccinations against tetanus, influenza virus, and pertussis. In 1961, a seminal study demonstrated the efficacy of maternal immunization with tetanus toxoid in the prevention of neonatal tetanus and reduction of neonatal mortality (155). Subsequently, the WHO MaternalNeonatal Tetanus (MNT) elimination program has resulted in the reduction of neonatal death due to tetanus from about 787,000 death in the late 1980 s to 59,000 death in 2008 (156). The final goal of the WHO campaign is to eliminate MNT, with elimination being defined at $<1$ case per 1000 live births.

Another case of successful maternal immunization is influenza vaccination. Influenza virus infection is a serious problem for pregnant women and immunization before, during, and after pregnancy substantially reduces serious clinical outcomes of infection. In addition, studies have demonstrated a protective effect on the child. Immunization of mothers leads to the increased transmission of maternal antibodies $(157,158)$, a $41-63 \%$ reduction in laboratory confirmed cases of influenza virus infection over a period of 6 months $(159,160)$, and a 39-91\% reduction in hospitalizations of newborns $(11,159)$.

In addition, immunization against pertussis with the acellular pertussis antigen vaccine has proven to increase the level of maternal antibodies (161-163) and protect infants from clinical pertussis (161). A meta-analysis of vaccination studies found that cocooning (immunization of all direct contacts of an infant) and maternal immunization significantly reduced clinical disease and also were found to be cost-effective from a payer's perspective (164). It should be noted that in these three examples inactivated vaccines were used. In principle, maternal immunization can be applied to other (live-attenuated) vaccines and infectious diseases as well. However, it has been reported that maternal immunization with a pneumococcal (polysaccharide) vaccine does not protect infants against clinical disease (165).

\section{PRINCIPAL QUESTIONS SURROUNDING MATERNAL IMMUNIZATION}

In order to study the effect of maternal immunization systematically, a number of questions have to be considered. For maternal immunization to be effective, antibodies have to be the immunological correlate of protection for the specific infectious disease and a specified level of protective titers has to be known as a target parameter to have an appreciable effect on clinical outcome. The main task is to determine the best time point and immunization schedule to immunize the mother. There is little information in the literature to guide immunization of mothers in order to obtain the best transfer of maternal antibodies. Current guidelines target immunizations of women with the goal to protect them and the fetus during pregnancy, and are usually divided in immunizations before and during pregnancy. In practical terms, mothers are often being immunized only when they are pregnant and usually immunization with inactivated rather than live-attenuated vaccines is recommended. A number of studies has found that maternal antibody titers in the child are higher than in the serum of the mother when these are low $(83,157)$ and lower than in the serum of the mother if the mother had high levels of antibodies. The cut-off seems to be a total IgG concentration of $15 \mathrm{~g} / \mathrm{L}$ (166). This phenomenon can be explained by the transport of $\operatorname{IgG}$ via the FcRn receptor across the placental barrier. If the FcRn receptor molecules are saturated, IgG will be degraded by lysosomal enzymes inside the vesicles (167). However, transfer of antibodies does not only depend on the total IgG concentration in the mother's blood but also on the isotype composition. The binding affinity of FcRn is highest for IgG1, followed by IgG4, IgG3 and is weakest for IgG2 (110). In consequence, more $\operatorname{IgG} 1$ is transported transplacentally than e.g., IgG2. This preferential transport mechanism explains why antibodies against specific vaccines are transported more efficiently than others. Usually, antibodies against $\mathrm{T}$ cell-dependent antigens (proteins) are of the IgG1 isotype and are more efficiently transported than antibodies against $\mathrm{T}$ cell-independent antigens (polysaccharides) of the IgG2 isotype. Based on these considerations, effective vaccines could be used to immunize expecting mothers in order to protect the neonates and infants. However, it is possible that for every vaccine a threshold of maternal antibody titers can be defined that cannot be changed even with very effective vaccines. This hypothesis has to be addressed experimentally in larger clinical studies.

Another factor influencing maternal antibody titers in children is gestational age. IgG transfer from mother to child starts at 13 weeks of age. However, in the third trimester the expression of FcRn receptors increases and subsequently the transfer rate of maternal antibodies improves with the highest amount of IgG (>50\%) transferred during the last 4 weeks before birth $(168,169)$. If relatively ineffective vaccines are available that do not induce long-lasting antibody responses, immunization during the third trimester of pregnancy might be an option. It has been demonstrated that a not very effective vaccine like pertussis might be beneficially applied during this time (170). An additional consideration for maternal immunization is the nutritional status of both mother and child. In general terms, nutrition influences immune responses but has not been shown to influence the level of antibody in the mother. However, it has been shown that undernourished children have lower maternal antibody titers, although the underlying reason is currently unknown (171). Other factors like maternal age, maternal weight, parity, and type of delivery do not influence transplacental antibody transfer (172).

In contrast to humans, immunization of agricultural animals is relatively straightforward as immunization schedules can be easily applied to breeder animals at any time. Overall, the prevailing view 
is that the time of immunization is not relevant as long as maternal antibody titers are high at birth because transfer occurs during a short window after birth and seems to be solely dependent on antibody titers in colostrum.

\section{EXAMPLE: HOW CAN MATERNAL IMMUNIZATION WORK AGAINST RESPIRATORY SYNCYTIAL VIRUS INFECTION?}

In order to answer the question of whether maternal immunization against a specific disease will lead to a reproducible and protective increase in antibody titers in children, one has to consider the total amount of IgG as well as the quality of antibody being induced by immunization. To illustrate these questions, I have chosen the example of immunization against RSV infection. RSV infection leads to severe respiratory infections in adults and is the second most common viral cause of death in the elderly (after influenza virus) (173). RSV infection is also the leading viral infection in lower respiratory disease in children, which is a particular problem in preterm babies and in neonates in their first months of life (174). So far, no vaccine or therapeutic is available. The discussion currently centers on the question of whether a vaccine could be developed that is safe and effective in neonates. Because the result of immunization of neonates is still elusive, an alternate suggestion is to use a to-be-developed vaccine to immunize mothers and provide protection for neonates and infants through maternal antibodies during the first 6 months of life. However, it is controversial as to whether maternal antibodies have a beneficial effect against RSV infection. RSV-specific antibodies are present in children during the first 6 months of life and have an estimated half-life of 1.5 months. Some studies have observed a protective effect of maternal antibodies (10, 175) whereas some did not [for review see Ref. (176)]. Currently, preterm infants (depending on their gestational age) are prophylactically treated with a monoclonal antibody against RSV. This prophylaxis is effective because the antibody has a high affinity $(177,178)$. In contrast to this antibody, naturally generated antibodies often have lower affinities resulting in lower neutralizing efficacy. In consequence, it will be important to induce high affinity antibodies in mothers through vaccination. Neutralizing antibodies against RSV bind to the fusion protein $(\mathrm{F})$ and the glycoprotein $(G)$. However, it has been demonstrated that vaccination with a RSV lacking the G protein is able to protect against viral challenge (179) and most attention in terms of vaccine development has been focused on the F protein. On the surface of the virion the fusion protein is folded so that the fusion peptide necessary to mediate fusion is protected from the environment (pre-fusion F). Upon triggering, the fusion protein unfolds and initiates fusion with the cellular membrane (postfusion F). Palivizumab, the antibody that prophylactically protects children against RSV infection binds to both pre- and post-fusion F. Recent publications have defined the structure of the pre- and post-fusion $\mathrm{F}$ protein and have demonstrated that the most effective in vitro neutralizing antibodies bind to the pre-fusion $\mathrm{F}$ thus leading to the assumption that the goal of vaccination has to be the increase of antibody against pre-fusion F (180-182). Based on this knowledge clinical studies should be devised that not only take the total amount of antibody into account but also measure the affinity of the antibody as well as its target ( $G$ protein and pre- as well as post-fusion F protein). Antibodies are being transferred transplacentally based on their ability to bind FcRn and not on their affinity to RSV, and this transfer seems to be saturable depending on antibody level in the maternal blood. If a relatively small proportion of antibody is of high affinity it might not be possible to reach high protective levels of maternal antibodies. Another concern is immunization in the presence of maternal antibodies. As with other infectious diseases, it has been shown that even low levels of maternal antibody inhibit RSV-specific B cell and antibody responses $(183,184)$, a problem that will still exist after increased transfer of maternal antibodies due to maternal immunization.

\section{SUMMARY AND OUTLOOK}

Many examples exist that demonstrate the inhibition of both human and veterinary vaccines by maternal antibodies. B cell inhibition is mediated through a cross-link between the BCR with the FcyRIIB by a vaccine-antibody complex. Knowledge of the underlying mechanisms helps us to understand the possibilities and limitations of our current clinical approaches and will help in the development and testing of new vaccines. This knowledge also will help us to evaluate and develop the concept of maternal immunization as a mechanism to protect infants against common infectious diseases. The potential benefit of maternal immunization is protection of the mother and a delayed susceptibility to infection of the child. However, by most estimates children will not be protected for more than 6 months of life whereas full immunological maturity seems to be accomplished only after 12 months. A final unanswered question about maternal immunization, however, is how to deal with immunization in the presence of maternal antibodies. In consequence, the question of vaccinating in the presence of maternal antibodies will remain and still has to be resolved.

\section{REFERENCES}

1. Siegrist CA, Aspinall R. B-cell responses to vaccination at the extremes of age. Nat Rev Immunol (2009) 9:185-94. doi:10.1038/nri2508

2. Butler JE, Lager KM, Splichal I, Francis D, Kacskovics I, Sinkora M, et al. The piglet as a model for B cell and immune system development. Vet Immunol Immunopathol (2009) 128:147-70. doi:10.1016/j.vetimm.2008.10.321

3. Chattha KS, Firth MA, Hodgins DC, Shewen PE. Expression of complement receptor 2 (CD21), membrane IgM and the inhibitory receptor CD32 (FcgammaRIIb) in the lymphoid tissues of neonatal calves. Vet Immunol Immunopathol (2010) 137:99-108. doi:10.1016/j.vetimm.2010.04.016

4. Chattha KS, Firth MA, Hodgins DC, Shewen PE. Variation in expression of membrane IgM, CD21 (CR2) and CD32 (Fcgamma RIIB) on bovine lymphocytes with age: a longitudinal study. Dev Comp Immunol (2010) 34:510-7. doi:10.1016/j.dci.2009.12.010

5. Morein B, Blomqvist G, Hu K. Immune responsiveness in the neonatal period. J Comp Pathol (2007) 137:S27-31. doi:10.1016/j.jcpa.2007.04.008

6. Heiman HS, Weisman LE. Transplacental or enteral transfer of maternal immunization-induced antibody protects suckling rats from type III group B streptococcal infection. Pediatr Res (1989) 26:629-32. doi:10.1203/00006450198912000-00023

7. Svet-Moldavsky GJ, Svet-Moldasky IA. Sarcomas in cotton rats inoculated with Rous virus. Science (1964) 143:54-5. doi:10.1126/science.143.3601.54

8. Zepeda M, Wilson JM. Neonatal cotton rats do not exhibit destructive immune responses to adenoviral vectors. Gene Ther (1996) 3:973-9.

9. Winkelstein JA, Marino MC, Lederman HM, Jones SM, Sullivan K, Burks AW, et al. X-linked agammaglobulinemia: report on a United States registry of 201 patients. Medicine (Baltimore) (2006) 85:193-202. doi:10.1097/01.md. 0000229482.27398.ad 
10. Ochola R, Sande C, Fegan G, Scott PD, Medley GF, Cane PA, et al. The level and duration of RSV-specific maternal IgG in infants in Kilifi Kenya. PLoS One (2009) 4:e8088. doi:10.1371/journal.pone.0008088

11. Benowitz I, Esposito DB, Gracey KD, Shapiro ED, Vazquez M. Influenza vaccine given to pregnant women reduces hospitalization due to influenza in their infants. Clin Infect Dis (2010) 51:1355-61. doi:10.1086/657309

12. Krakowka S, Long D, Koestner A. Influence of transplacentally acquired antibody on neonatal susceptibility to canine distemper virus in gnotobiotic dogs. J Infect Dis (1978) 137:605-8. doi:10.1093/infdis/137.5.605

13. Li X, Dong X, Sun X, Li W, Zhao P, Cui Z, et al. Preparation and immunoprotection of subgroup B avian leukosis virus inactivated vaccine. Vaccine (2013) 31:5479-85. doi:10.1016/j.vaccine.2013.08.072

14. Leuridan E, Hens N, Hutse V, Aerts M, Van Damme P. Kinetics of maternal antibodies against rubella and varicella in infants. Vaccine (2011) 29:2222-6. doi:10.1016/j.vaccine.2010.06.004

15. Leuridan E, Van Damme P. Passive transmission and persistence of naturally acquired or vaccine-induced maternal antibodies against measles in newborns. Vaccine (2007) 25:6296-304. doi:10.1016/j.vaccine.2007.06.020

16. Kilic A, Altinkaynak S, Ertekin V, Inandi T. The duration of maternal measles antibodies in children. J Trop Pediatr (2003) 49:302-5. doi:10.1093/tropej/49. 5.302

17. Watanaveeradej V, Endy TP, Samakoses R, Kerdpanich A, Simasathien S, Polprasert N, et al. Transplacentally transferred maternal-infant antibodies to dengue virus. Am J Trop Med Hyg (2003) 69:123-8.

18. Awa DN, Ngagnou A, Tefiang E, Yaya D, Njoya A. Post vaccination and colostral peste des petits ruminants antibody dynamics in research flocks of Kirdi goats and Foulbe sheep of north Cameroon. Prev Vet Med (2002) 55:265-71. doi:10.1016/S0167-5877(02)00013-2

19. Tsutsui T, Yamamoto T, Hayama Y, Akiba Y, Nishiguchi A, Kobayashi S, et al. Duration of maternally derived antibodies against Akabane virus in calves: survival analysis. J Vet Med Sci (2009) 71:913-8. doi:10.1292/jvms.71.913

20. Winters WD, Clouse WJ, Harris SC. Concomitant transfer of BCG-CW and canine virus antibodies from dams to pups. Dev Comp Immunol (1981) 5:321-8. doi:10.1016/0145-305X(81)90039-2

21. Gharaibeh S, Mahmoud K. Decay of maternal antibodies in broiler chickens. Poult Sci (2013) 92:2333-6. doi:10.3382/ps.2013-03249

22. Epstein JH, Baker ML, Zambrana-Torrelio C, Middleton D, Barr JA, Dubovi E, et al. Duration of maternal antibodies against canine distemper virus and hendra virus in pteropid bats. PLoS One (2013) 8:e67584. doi:10.1371/journal. pone.0067584

23. Sohayati AR, Hassan L, Sharifah SH, Lazarus K, Zaini CM, Epstein JH, et al. Evidence for Nipah virus recrudescence and serological patterns of captive Pteropus vampyrus. Epidemiol Infect (2011) 139:1570-9. doi:10.1017/ S0950268811000550

24. Baker KS, Suu-Ire R, Barr J, Hayman DTS, Broder CC, Horton DL, et al. Viral antibody dynamics in a chiropteran host. J Anim Ecol (2014) 83:415-28. doi:10.1111/1365-2656.12153

25. Jones C, Pollock L, Barnett SM, Battersby A, Kampmann B. The relationship between concentration of specific antibody at birth and subsequent response to primary immunization. Vaccine (2014) 32:996-1002. doi:10.1016/j.vaccine. 2013.11.104

26. Francis JP, Richmond PC, Pomat WS, Michael A, Keno H, Phuanukoonnon $\mathrm{S}$, et al. Maternal antibodies to pneumolysin but not to pneumococcal surface protein a delay early pneumococcal carriage in high-risk Papua new Guinean infants. Clin Vaccine Immunol (2009) 16:1633-8. doi:10.1128/CVI.00247-09

27. Kurikka S, Kayhty H, Peltola H, Saarinen L, Eskola J, Makela PH. Neonatal immunization: response to Haemophilus influenzae type b-tetanus toxoid conjugate vaccine. Pediatrics (1995) 95:815-22.

28. Englund JA, Anderson EL, Reed GF, Decker MD, Edwards KM, Pichichero $\mathrm{ME}$, et al. The effect of maternal antibody on the serologic response and the incidence of adverse reactions after primary immunization with acellular and whole-cell pertussis vaccines combined with diphtheria and tetanus toxoids. Pediatrics (1995) 96:580-4.

29. Whittle H, Hanlon P, O’Neil K, Hanlon L, Marsh V, Jupp E. Trial of highdose Edmonston-Zagreb measles vaccine in Gambia: antibody response and side-effects. Lancet (1988) 2:811-4. doi:10.1016/S0140-6736(88)92781-X

30. Garly ML, Bale C, Martins CL, Monteiro M, George E, Kidd M, et al Measles antibody responses after early two dose trials in Guinea-Bissau with
Edmonston-Zagreb and Schwarz standard-titre measles vaccine: better antibody increase from booster dose of the Edmonston-Zagreb vaccine. Vaccine (2001) 19:1951-9. doi:10.1016/S0264-410X(00)00431-X

31. Borras E, Urbiztondo L, Costa J, Batalla J, Torner N, Plasencia A, et al. Measles antibodies and response to vaccination in children aged less than 14 months: implications for age of vaccination. Epidemiol Infect (2012) 140:1599-606. doi:10.1017/S0950268811002184

32. Gans H, Dehovitz R, Forghani B, Beeler J, Maldonado Y, Arvin AM. Measles and mumps vaccination as a model to investigate the developing immune system: passive and active immunity during the first year of life. Vaccine (2003) 21:3398-405. doi:10.1016/S0264-410X(03)00341-4

33. Letson GW, Shapiro CN, Kuehn D, Gardea C, Welty TK, Krause DS, et al. Effect of maternal antibody on immunogenicity of hepatitis A vaccine in infants. J Pediatr (2004) 144:327-32. doi:10.1016/j.jpeds.2003.11.030

34. Hu Y, Wu Q, Xu B, Zhou Z, Wang Z, Zhou YH. Influence of maternal antibody against hepatitis $B$ surface antigen on active immune response to hepatitis B vaccine in infants. Vaccine (2008) 26:6064-7. doi:10.1016/j.vaccine. 2008.09.014

35. Appaiahgari MB, Glass R, Singh S, Taneja S, Rongsen-Chandola T, Bhandari $\mathrm{N}$, et al. Transplacental rotavirus IgG interferes with immune response to live oral rotavirus vaccine ORV-116E in Indian infants. Vaccine (2014) 32:651-6. doi:10.1016/j.vaccine.2013.12.017

36. Sormunen H, Stenvik M, Eskola J, Hovi T. Age- and dose-interval-dependent antibody responses to inactivated poliovirus vaccine. J Med Virol (2001) 63:305-10. doi:10.1002/1096-9071(200104)63:4<305::AID-JMV1006>3.0 $\mathrm{CO} ; 2-\mathrm{U}$

37. Simoes EA, Padmini B, Steinhoff MC, Jadhav M, John TJ. Antibody response of infants to two doses of inactivated poliovirus vaccine of enhanced potency. Am J Dis Child (1985) 139:977-80.

38. Warren RJ, Lepow ML, Bartsch GE, Robbins FC. The relationship of maternal antibody. Pediatrics (1964) 34:4-13.

39. Piedra PA, Glezen WP, Mbawuike I, Gruber WC, Baxter BD, Boland FJ, et al. Studies on reactogenicity and immunogenicity of attenuated bivalent cold recombinant influenza type A (CRA) and inactivated trivalent influenza virus (TI) vaccines in infants and young children. Vaccine (1993) 11:718-24. doi:10.1016/0264-410X(93)90255-V

40. Pollock RV, Carmichael LE. Maternally derived immunity to canine parvovirus infection: transfer, decline, and interference with vaccination. J Am Vet Med Assoc (1982) 180:37-42.

41. Waner T, Naveh A, Wudovsky I, Carmichael LE. Assessment of maternal antibody decay and response to canine parvovirus vaccination using a clinic-based enzyme-linked immunosorbent assay. J Vet Diagn Invest (1996) 8:427-32. doi:10.1177/104063879600800404

42. Iida H, Fukuda S, Kawashima N, Yamazaki T, Aoki J, Tokita K, et al. [Effect of maternally derived antibody levels on antibody responses to canine parvovirus, canine distemper virus and infectious canine hepatitis virus after vaccinations in beagle puppies] article in Japanese. Jikken Dobutsu (1990) 39:9-19.

43. Chappuis G. Control of canine distemper. Vet Microbiol (1995) 44:351-8. doi:10.1016/0378-1135(95)00028-9

44. Digangi BA, Levy JK, Griffin B, Reese MJ, Dingman PA, Tucker SJ, et al. Effects of maternally-derived antibodies on serologic responses to vaccination in kittens. J Feline Med Surg (2012) 14:118-23. doi:10.1177/1098612X11432239

45. Jakel V, Cussler K, Hanschmann KM, Truyen U, Konig M, Kamphuis E, et al. Vaccination against Feline Panleukopenia: implications from a field study in kittens. BMC Vet Res (2012) 8:62. doi:10.1186/1746-6148-8-62

46. Downey ED, Tait RG Jr, Mayes MS, Park CA, Ridpath JF, Garrick DJ, et al. An evaluation of circulating bovine viral diarrhea virus type 2 maternal antibody level and response to vaccination in Angus calves. J Anim Sci (2013) 91:4440-50. doi:10.2527/jas.2012-5890

47. Endsley JJ, Roth JA, Ridpath J, Neill J. Maternal antibody blocks humoral but not T cell responses to BVDV. Biologicals (2003) 31:123-5. doi:10.1016/S10451056(03)00027-7

48. Patil PK, Sajjanar CM, Natarajan C, Bayry J. Neutralizing antibody responses to foot-and-mouth disease quadrivalent (type $\mathrm{O}, \mathrm{A}, \mathrm{C}$ and Asia 1) vaccines in growing calves with pre-existing maternal antibodies. Vet Microbiol (2014) 169(3-4):233-5. doi:10.1016/j.vetmic.2014.01.005

49. Ellis JA, Gow SP, Goji N. Response to experimentally induced infection with bovine respiratory syncytial virus following intranasal vaccination of 
seropositive and seronegative calves. J Am Vet Med Assoc (2010) 236:991-9. doi:10.2460/javma.236.9.991

50. Ellis JA, Gow SP, Mahan S, Leyh R. Duration of immunity to experimental infection with bovine respiratory syncytial virus following intranasal vaccination of young passively immune calves. J Am Vet Med Assoc (2013) 243:1602-8. doi:10.2460/javma.243.11.1602

51. van der Sluijs MT, Kuhn EM, Makoschey B. A single vaccination with an inactivated bovine respiratory syncytial virus vaccine primes the cellular immune response in calves with maternal antibody. BMC Vet Res (2010) 11(6):2. doi:10.1186/1746-6148-6-2

52. Pomorska-Mol M, Markowska-Daniel I, Pejsak Z. Effect of age and maternallyderived antibody status on humoral and cellular immune responses to vaccination of pigs against Erysipelothrix rhusiopathiae. Vet J (2012) 194:128-30. doi:10.1016/j.tvjl.2012.03.009

53. Pomorska-Mol M, Markowska-Daniel I, Pejsak Z. Evaluation of humoral and antigen-specific T-cell responses after vaccination of pigs against pseudorabies in the presence of maternal antibodies. Vet Microbiol (2010) 144:450-4. doi:10.1016/j.vetmic.2010.01.015

54. Klinkenberg D, Moormann RJ, De Smit AJ, Bouma A, De Jong MC. Influence of maternal antibodies on efficacy of a subunit vaccine: transmission of classical swine fever virus between pigs vaccinated at 2 weeks of age. Vaccine (2002) 20:3005-13. doi:10.1016/S0042-207X(02)00283-X

55 . Suradhat S, Damrongwatanapokin S. The influence of maternal immunity on the efficacy of a classical swine fever vaccine against classical swine fever virus, genogroup 2.2, infection. Vet Microbiol (2003) 92:187-94. doi:10.1016/S03781135(02)00357-7

56. Markowska-Daniel I, Pomorska-Mol M, Pejsak Z. The influence of age and maternal antibodies on the postvaccinal response against swine influenza viruses in pigs. Vet Immunol Immunopathol (2011) 142:81-6. doi:10.1016/j. vetimm.2011.03.019

57. Forrest HL, Garcia A, Danner A, Seiler JP, Friedman K, Webster RG, et al. Effect of passive immunization on immunogenicity and protective efficacy of vaccination against a Mexican low-pathogenic avian H5N2 influenza virus. Influenza Other Respir Viruses (2013) 7:1194-201. doi:10.1111/irv.12140

58. Fry TL, Vandalen KK, Shriner SA, Moore SM, Hanlon CA, Vercauteren KC. Humoral immune response to oral rabies vaccination in raccoon kits: problems and implications. Vaccine (2013) 31:2811-5. doi:10.1016/j.vaccine. 2013.04.016

59. Pare JA, Barker IK, Crawshaw GJ, Mcewen SA, Carman PS, Johnson RP. Humoral response and protection from experimental challenge following vaccination of raccoon pups with a modified-live canine distemper virus vaccine. J Wildl Dis (1999) 35:430-9. doi:10.7589/0090-3558-35.3.430

60. Maia OB, Gouveia AM. Serologic response of maned wolves (Chrysocyon brachyurus) to canine distemper virus and canine parvovirus vaccination. JZoo Wildl Med (2001) 32:78-80.

61. Welter J, Taylor J, Tartaglia J, Paoletti E, Stephensen CB. Vaccination against canine distemper virus infection in infant ferrets with and without maternal antibody protection, using recombinant attenuated poxvirus vaccines. $J$ Virol (2000) 74:6358-67. doi:10.1128/JVI.74.14.6358-6367.2000

62. Katz SL. John F. Enders and measles virus vaccine-a reminiscence. Curr Top Microbiol Immunol (2009) 329:3-11.

63. Parks CL, Lerch RA, Walpita P, Wang HP, Sidhu MS, Udem SA. Comparison of predicted amino acid sequences of measles virus strains in the Edmonston vaccine lineage. J Virol (2001) 75:910-20. doi:10.1128/JVI.75.2.910-920.2001

64. Low N, Kraemer S, Schneider M, Restrepo AM. Immunogenicity and safety of aerosolized measles vaccine: systematic review and meta-analysis. Vaccine (2008) 26:383-98. doi:10.1016/j.vaccine.2007.11.010

65. Griffin DE, Pan C-H. Measles: old vaccines and new vaccines. In: Griffin DE, Oldstone MBA, editors. Measles - Pathogenesis and Control. Heidelberg: Springer Verlag (2009). p. 191-212.

66. Griffin DE, Ward BJ, Esolen LM. Pathogenesis of measles virus infection: an hypothesis for altered immune responses. J Infect Dis (1994) 170(Suppl 1):S24-31. doi:10.1093/infdis/170.Supplement_1.S24

67. Permar SR, Klumpp SA, Mansfield KG, Kim WK, Gorgone DA, Lifton MA, et al. Role of CD8 (+) lymphocytes in control and clearance of measles virus infection of rhesus monkeys. J Virol (2003) 77:4396-400. doi:10.1128/JVI.77. 7.4396-4400.2003
68. Pueschel K, Tietz A, Carsillo M, Steward M, Niewiesk S. Measles virus-specific CD4 T-cell activity does not correlate with protection against lung infection or viral clearance. J Virol (2007) 81:8571-8. doi:10.1128/JVI.00160-07

69. Finke D, Liebert UG. CD4+ T cells are essential in overcoming experimental murine measles encephalitis. Immunology (1994) 83:184-9.

70. Weidinger G, Henning G, Ter Meulen V, Niewiesk S. Inhibition of major histocompatibility complex class II-dependent antigen presentation by neutralization of gamma interferon leads to breakdown of resistance against measles virus-induced encephalitis. J Virol (2001) 75:3059-65. doi:10.1128/JVI.75.7. 3059-3065.2001

71. McNulty J, Nair JJ, Griffin C, Pandey S. synthesis and biological evaluation of fully functionalized seco-pancratistatin analogues. J Nat Prod (2008) 71:357-63. doi:10.1021/np0705460

72. Aaby P, Martins CL, Garly ML, Andersen A, Fisker AB, Claesson MH, et al. Measles vaccination in the presence or absence of maternal measles antibody: impact on child survival. Clin Infect Dis (2014) 59(4):484-92. doi:10.1093/cid/ ciu354

73. Samb B, Aaby P, Whittle HC, Seck AM, Rahman S, Bennett J, et al. Serologic status and measles attack rates among vaccinated and unvaccinated children in rural Senegal. Pediatr Infect Dis J (1995) 14:203-9. doi:10.1097/00006454199503000-00007

74. Gans H, Yasukawa L, Rinki M, Dehovitz R, Forghani B, Beeler J, et al. Immune responses to measles and mumps vaccination of infants at 6,9, and 12 months. J Infect Dis (2001) 184:817-26. doi:10.1086/323346

75. Gans HA, Yasukawa LL, Alderson A, Rinki M, Dehovitz R, Beeler J, et al. Humoral and cell-mediated immune responses to an early 2-dose measles vaccination regimen in the United States. J Infect Dis (2004) 190:83-90. doi:10.1086/421032

76. Njie-Jobe J, Nyamweya S, Miles DJ, Van Der Sande M, Zaman S, Touray E, et al. Immunological impact of an additional early measles vaccine in Gambian children: responses to a boost at 3 years. Vaccine (2012) 30:2543-50. doi:10.1016/j.vaccine.2012.01.083

77. Bertley FM, Ibrahim SA, Libman M, Ward BJ. Measles vaccination in the presence of maternal antibodies primes for a balanced humoral and cellular response to revaccination. Vaccine (2004) 23:444-9. doi:10.1016/j.vaccine. 2004.06.021

78. Aaby P, Jensen T, Hansen H. Trial of high dose Edmonston-Zagreb measles vaccine in Guinea-Bissau: protective efficacy. Lancet (1988) 2:809-11. doi:10. 1016/S0140-6736(88)92780-8

79. Garenne M, Leroy O, Beau J, Sene I. Child mortality after high titer measles vaccine: prospective study in Senegal. Lancet (1991) 338:903-7. doi:10.1016/ 0140-6736(91)91771-L

80. Halsey N. Increased mortality following high titer measles vaccines: too much good thing. Pediatr Infect Dis J (1993) 12:462-5. doi:10.1097/00006454199306000-00002

81. Seng R, Samb B, Simondon F, Cisse B, Soumare M, Jensen H, et al. Increased long term mortality associated with rash after early measles vaccination in rural Senegal. Pediatr Infect Dis J (1999) 18:48-52. doi:10.1097/00006454199901000-00012

82. Martins C, Bale C, Garly ML, Rodrigues A, Lisse IM, Andersen A, et al. Girls may have lower levels of maternal measles antibodies and higher risk of subclinical measles infection before the age of measles vaccination. Vaccine (2009) 27:5220-5. doi:10.1016/j.vaccine.2009.06.076

83. Techasena W, Sriprasert P, Pattamadilok S, Wongwacharapipoon P. Measles antibody in mothers and infants 0-2 years and response to measles vaccine at the age of 9 and 18 months. J Med Assoc Thai (2007) 90:106-12.

84. Gans HA, Arvin AM, Galinus J, Logan L, Dehovitz R, Maldonado Y. Deficiency of the humoral immune response to measles vaccine in infants immunized at age 6 months. JAMA (1998) 280:527-32. doi:10.1001/jama.280.6.527

85. Johnson CE, Darbari A, Darbari DS, Nalin D, Whitwell J, Chui LW, et al. Measles vaccine immunogenicity and antibody persistence in 12 vs 15-month old infants. Vaccine (2000) 18:2411-5. doi:10.1016/S0264-410X(99) 00574-5

86. Martins CL, Garly ML, Bale C, Rodrigues A, Ravn H, Whittle HC, et al. Protective efficacy of standard Edmonston-Zagreb measles vaccination in infants aged 4.5 months: interim analysis of a randomised clinical trial. Br Med J (2008) 337:a661. doi:10.1136/bmj.a661 
87. Gagneur A, Pinquier D, Aubert M, Balu L, Brissaud O, De Pontual L, et al. Kinetics of decline of maternal measles virus-neutralizing antibodies in sera of infants in France in 2006. Clin Vaccine Immunol (2008) 15:1845-50. doi:10.1128/CVI.00229-08

88. Oyedele OO, Odemuyiwa SO, Ammerlaan W, Muller CP, Adu FD. Passive immunity to measles in the breastmilk and cord blood of some nigerian subjects. J Trop Pediatr (2005) 51:45-8. doi:10.1093/tropej/fmh073

89. Szenborn L, Tischer A, Pejcz J, Rudkowski Z, Wojcik M. Passive acquired immunity against measles in infants born to naturally infected and vaccinated mothers. Med Sci Monit (2003) 9:CR541-6.

90. Pomorska-Mol M, Markowska-Daniel I. Interferon-gamma secretion and proliferative responses of peripheral blood mononuclear cells after vaccination of pigs against Aujeszky's disease in the presence of maternal immunity. FEMS Immunol Med Microbiol (2010) 58:405-11. doi:10.1111/j.1574-695X 2010.00651.x

91. Rodewald R, Kraehenbuhl JP. Receptor-mediated transport of IgG. J Cell Biol (1984) 99:159s-64s. doi:10.1083/jcb.99.1.159s

92. Simister NE, Mostov KE. An Fc receptor structurally related to MHC class I antigens. Nature (1989) 337:184-7. doi:10.1038/337184a0

93. Costa-Carvalho BT, Vieria HM, Dimantas RB, Arslanian C, Naspitz CK, Sole D, et al. Transfer of IgG subclasses across placenta in term and preterm newborns. Braz J Med Biol Res (1996) 29:201-4.

94. Hurley WL, Theil PK. Perspectives on immunoglobulins in colostrum and milk. Nutrients (2011) 3(4):442-74. doi:10.3390/nu3040442

95. Rodewald R. Selective antibody transport in the proximal small intestine of the neonatal rat. J Cell Biol (1970) 45:635-40. doi:10.1083/jcb.45.3.635

96. Jones EA, Waldmann TA. The mechanism of intestinal uptake and transcellular transport of IgG in the neonatal rat. J Clin Invest (1972) 51:2916-27. doi:10.1172/JCI107116

97. Rodewald R. Intestinal transport of antibodies in the newborn rat. J Cell Biol (1973) 58:189-211. doi:10.1083/jcb.58.1.189

98. Rodewald R. Distribution of immunoglobulin G receptors in the small intestine of the young rat. J Cell Biol (1980) 85:18-32. doi:10.1083/jcb.85.1.18

99. Favaron PO, Carter AM, Ambrosio CE, Morini AC, Mess AM, De Oliveira MF et al. Placentation in Sigmodontinae: a rodent taxon native to South America. Reprod Biol Endocrinol (2011) 9:55. doi:10.1186/1477-7827-9-55

100. Prince GA, Horswood RL, Camargo E, Koenig D, Chanock RM. Mechanisms of immunity to respiratory syncytial virus in cotton rats. Infect Immun (1983) 42:81-7.

101. Winters WD. Time dependent decreases of maternal canine virus antibodies in newborn pups. Vet Rec (1981) 108:295-9. doi:10.1136/vr.108.14.295

102. Omata Y, Oikawa H, Kanda M, Mikazuki K, Dilorenzo C, Claveria FG, et al Transfer of antibodies to kittens from mother cats chronically infected with Toxoplasma gondii. Vet Parasitol (1994) 52:211-8. doi:10.1016/0304-4017(94) 90113-9

103. Casal ML, Jezyk PF, Giger U. Transfer of colostral antibodies from queens to their kittens. Am J Vet Res (1996) 57:1653-8.

104. Claus MA, Levy JK, Macdonald K, Tucker SJ, Crawford PC. Immunoglobulin concentrations in feline colostrum and milk, and the requirement of colostrum for passive transfer of immunity to neonatal kittens. J Feline Med Surg (2006) 8:184-91. doi:10.1016/j.jfms.2006.01.001

105. Bourne FJ, Curtis J. The transfer of immunoglobins IgG, IgA and IgM from serum to colostrum and milk in the sow. Immunology (1973) 24:157-62.

106. Stirling CM, Charleston B, Takamatsu H, Claypool S, Lencer W, Blumberg $\mathrm{RS}$, et al. Characterization of the porcine neonatal Fc receptor - potential use for trans-epithelial protein delivery. Immunology (2005) 114:542-53. doi:10.1111/j.1365-2567.2004.02121.x

107. Cervenak J, Kacskovics I. The neonatal Fc receptor plays a crucial role in the metabolism of IgG in livestock animals. Vet Immunol Immunopathol (2009) 128:171-7. doi:10.1016/j.vetimm.2008.10.300

108. Cutting JA, Roth TF. Changes in specific sequestration of protein during transport into the developing oocyte of the chicken. Biochim Biophys Acta (1973) 298:951-5. doi:10.1016/0005-2736(73)90398-2

109. West AP Jr, Herr AB, Bjorkman PJ. The chicken yolk sac IgY receptor, a functional equivalent of the mammalian MHC-related Fc receptor, is a phospholipase A2 receptor homolog. Immunity (2004) 20:601-10. doi:10.1016/S10747613(04)00113-X
110. Palmeira P, Quinello C, Silveira-Lessa AL, Zago CA, Carneiro-Sampaio M. IgG placental transfer in healthy and pathological pregnancies. Clin Dev Immunol (2012) 2012:985646. doi:10.1155/2012/985646

111. Staley TE, Bush LJ. Receptor mechanisms of the neonatal intestine and their relationship to immunoglobulin absorption and disease. J Dairy Sci (1985) 68:184-205. doi:10.3168/jds.S0022-0302(85)80812-2

112. Lecce JG, Morgan DO. Effect of dietary regimen on cessation of intestinal absorption of large molecules (closure) in the neonatal pig and lamb. J Nutr (1962) 78:263-8.

113. Ober RJ, Radu CG, Ghetie V, Ward ES. Differences in promiscuity for antibodyFcRn interactions across species: implications for therapeutic antibodies. Int Immunol (2001) 13:1551-9. doi:10.1093/intimm/13.12.1551

114. Kim D, Huey D, Oglesbee M, Niewiesk S. Insights into the regulatory mechanism controlling the inhibition of vaccine-induced seroconversion by maternal antibodies. Blood (2011) 117:6143-51. doi:10.1182/blood-2010-11-320317

115. Bruhns P, Iannascoli B, England P, Mancardi DA, Fernandez N, Jorieux S, et al. Specificity and affinity of human Fcgamma receptors and their polymorphic variants for human IgG subclasses. Blood (2009) 113:3716-25. doi:10.1182/blood-2008-09-179754

116. Willcocks LC, Smith KG, Clatworthy MR. Low-affinity Fcgamma receptors, autoimmunity and infection. Expert Rev Mol Med (2009) 11:e24. doi:10.1017/ S1462399409001161

117. Prince GA, Horswood RL, Camargo E, Suffin SC, Chanock RM. Parenteral immunization with live respiratory syncytial virus is blocked in seropositive cotton rats. Infect Immun (1982) 37:1074-8.

118. Murphy BR, Olmsted RA, Collins PL, Chanock RM, Prince GA. Passive transfer of respiratory syncytial virus (RSV) antiserum suppresses the immune response to the RSV fusion (F) and large (G) glycoproteins expressed by recombinant vaccinia viruses. J Virol (1988) 62:3907-10.

119. De Groot AS, Moise L, Mcmurry JA, Wambre E, Van Overtvelt L, Moingeon P, et al. Activation of natural regulatory $\mathrm{T}$ cells by IgG Fc-derived peptide "Tregitopes”. Blood (2008) 112:3303-11. doi:10.1182/blood-2008-02-138073

120. Bruggemann M, Rajewsky K. Regulation of the antibody response against hapten-coupled erythrocytes by monoclonal antihapten antibodies of various isotypes. Cell Immunol (1982) 71:365-73. doi:10.1016/0008-8749(82)90270-2

121. Heyman B, Wigzell H. Immunoregulation by monoclonal sheep erythrocytespecific IgG antibodies: suppression is correlated to level of antigen binding and not to isotype. J Immunol (1984) 132:1136-43.

122. Karlsson MC, Wernersson S, Diaz, De Stahl T, Gustavsson S, Heyman B. Efficient IgG-mediated suppression of primary antibody responses in Fcgamma receptor-deficient mice. Proc Natl Acad Sci U S A (1999) 96:2244-9. doi:10. 1073/pnas.96.5.2244

123. Getahun A, Heyman B. Studies on the mechanism by which antigen-specific IgG suppresses primary antibody responses: evidence for epitope masking and decreased localization of antigen in the spleen. Scand J Immunol (2009) 70:277-87. doi:10.1111/j.1365-3083.2009.02298.x

124. Karlsson MC, Getahun A, Heyman B. FcgammaRIIB in IgG-mediated suppression of antibody responses: different impact in vivo and in vitro. J Immunol (2001) 167:5558-64. doi:10.4049/jimmunol.167.10.5558

125. Heyman B, Pilstrom L, Shulman MJ. Complement activation is required for IgM-mediated enhancement of the antibody response. J Exp Med (1988) 167:1999-2004. doi:10.1084/jem.167.6.1999

126. Heyman B, Nose M, Weigle WO. Carbohydrate chains on IgG2b: a requirement for efficient feedback immunosuppression. J Immunol (1985) 134:4018-23.

127. Sinclair NR, Lees RK, Elliott EV. Role of the Fc fragment in the regulation of the primary immune response. Nature (1968) 220:1048-9. doi:10.1038/2201048a0

128. Sinclair NR. Regulation of the immune response. J Exp Med (1969) 129:1183-201. doi:10.1084/jem.129.6.1183

129. Lyubchenko T, Dal Porto J, Cambier JC, Holers VM. Coligation of the B cell receptor with complement receptor type 2 (CR2/CD21) using its natural ligand C3dg: activation without engagement of an inhibitory signaling pathway. J Immunol (2005) 174:3264-72. doi:10.4049/jimmunol.174.6.3264

130. Thornton BP, Vetvicka V, Ross GD. Function of C3 in a humoral response: $\mathrm{iC} 3 \mathrm{~b} / \mathrm{C} 3 \mathrm{dg}$ bound to an immune complex generated with natural antibody and a primary antigen promotes antigen uptake and the expression of costimulatory molecules by all B cells, but only stimulates immunoglobulin synthesis by antigen-specific B cells. Clin Exp Immunol (1996) 104:531-7. 
131. Fearon DT, Carroll MC. Regulation of B lymphocyte responses to foreign and self-antigens by the CD19/CD21 complex. Annu Rev Immunol (2000) 18:393-422. doi:10.1146/annurev.immunol.18.1.393

132. Applequist SE, Dahlstrom J, Jiang N, Molina H, Heyman B. Antibody production in mice deficient for complement receptors 1 and 2 can be induced by IgG/Ag and IgE/Ag, but not IgM/Ag complexes. J Immunol (2000) 165:2398-403. doi:10.4049/jimmunol.165.5.2398

133. Anderson CF, Mosser DM. Cutting edge: biasing immune responses by directing antigen to macrophage Fc gamma receptors. J Immunol (2002) 168:3691-701. doi:10.4049/jimmunol.168.8.3697

134. Schlereth B, Buonocore L, Tietz A, Ter Meulen V, Rose JK, Niewiesk S. Successful mucosal immunization of cotton rats in the presence of measles virus-specific antibodies depends on degree of attenuation of vaccine vector and virus dose. J Gen Virol (2003) 84:2145-51. doi:10.1099/vir.0.19050-0

135. Weidinger G, Ohlmann M, Schlereth B, Sutter G, Niewiesk S. Vaccination with recombinant modified vaccinia virus Ankara protects against measles virus infection in the mouse and cotton rat model. Vaccine (2001) 19:2764-8. doi:10.1016/S0264-410X(00)00531-4

136. Schlereth B, Germann PG, ter Meulen V, Niewiesk S. DNA vaccination with the hemagglutinin and the fusion proteins, but not the nucleocapsid protein protects against experimental measles virus infection. J Gen Virol (2000) 81:1321-5.

137. Kim D, Niewiesk S. Synergistic induction of interferon alpha through TLR3 and TLR-9 agonists identifies CD21 as interferon alpha receptor for the B Cell response. PLoS Pathog (2013) 9:e1003233. doi:10.1371/journal.ppat. 1003233

138. Siegrist C-A, Plotnicky-Gilquin H, Cordova M, Berney M, Bonnefoy J-Y, Nguyen TN, et al. Protective efficacy against respiratory syncytial virus following murine neonatal immunization with BBG2Na vaccine: influence of adjuvants and maternal antibodies. J Infect Dis (1999) 179:1326-33. doi:10. $1086 / 314778$

139. Delcayre AX, Salas F, Mathur S, Kovats K, Lotz M, Lernhardt W. Epstein Barr virus/complement C3d receptor is an interferon alpha receptor. EMBOJ (1991) 10:919-26.

140. Asokan R, Hua J, Young KA, Gould HJ, Hannan JP, Kraus DM, et al. Characterization of human complement receptor type 2 (CR2/CD21) as a receptor for IFN-alpha: a potential role in systemic lupus erythematosus. J Immunol (2006) 177:383-94. doi:10.4049/jimmunol.177.1.383

141. Kim D, Niewiesk S. Synergistic induction of interferon a through TLR-3 and TLR-9 agonists stimulates immune responses against measles virus in neonatal cotton rats. Vaccine (2014) 32(2):265-70. doi:10.1016/j.vaccine.2013.11.013

142. Niewiesk S. Current animal models: cotton rat. In: Griffin DE, Oldstone MBA, editors. Measles - Pathogenesis and Control. Heidelberg: Springer Verlag (2009). p. $89-110$.

143. Nimmerjahn F, Ravetch JV. Fcgamma receptors as regulators of immune responses. Nat Rev Immunol (2008) 8:34-47. doi:10.1038/nri2206

144. Enriquez-Rincon F, Klaus GG. Differing effects of monoclonal anti-hapten antibodies on humoral responses to soluble or particulate antigens. Immunology (1984) 52:129-36.

145. Harris JR, Markl J. Keyhole limpet hemocyanin (KLH): a biomedical review. Micron (1999) 30:597-623. doi:10.1016/S0968-4328(99)00036-0

146. Daikoku E, Morita C, Kohno T, Sano K. Analysis of morphology and infectivity of measles virus particles. Bull Osaka Med Coll (2007) 53:107-14.

147. Bouche FB, Ertl OT, Muller CP. Neutralizing B cell responses in measles. Viral Immunol (2002) 15:451-72. doi:10.1089/088282402760312331

148. Kozlowski PA, Cu-Uvin S, Neutra MR, Flanigan TP. Comparison of the oral, rectal, and vaginal immunization routes for induction of antibodies in rectal and genital tract secretions of women. Infect Immun (1997) 65:1387-94.

149. Yoshida M, Masuda A, Kuo TT, Kobayashi K, Claypool SM, Takagawa T, et al. IgG transport across mucosal barriers by neonatal Fc receptor for IgG and mucosal immunity. Springer Semin Immunopathol (2006) 28:397-403. doi:10.1007/s00281-006-0054-z

150. Vincent AL, Ma W, Lager KM, Richt JA, Janke BH, Sandbulte MR, et al. Live attenuated influenza vaccine provides superior protection from heterologous infection in pigs with maternal antibodies without inducing vaccine-associated enhanced respiratory disease. J Virol (2012) 86:10597-605. doi:10.1128/JVI. 01439- 12
151. Sarfati-Mizrahi D, Lozano-Dubernard B, Soto-Priante E, Castro-Peralta F, Flores-Castro R, Loza-Rubio E, et al. Protective dose of a recombinant Newcastle disease LaSota-avian influenza virus $\mathrm{H} 5$ vaccine against $\mathrm{H} 5 \mathrm{~N} 2$ highly pathogenic avian influenza virus and velogenic viscerotropic Newcastle disease virus in broilers with high maternal antibody levels. Avian Dis (2010) 54:239-41. doi:10.1637/8735-032509-Reg.1

152. Blasco E, Lambot M, Barrat J, Cliquet F, Brochier B, Renders C, et al. Kinetics of humoral immune response after rabies VR-G oral vaccination of captive fox cubs (Vulpes vulpes) with or without maternally derived antibodies against the vaccine. Vaccine (2001) 19:4805-15. doi:10.1016/S0264-410X(01) 00211-0

153. Zhou X, Wang D, Xiong J, Zhang P, Li Y, She R. Protection of chickens, with or without maternal antibodies, against IBDV infection by a recombinant IBDVVP2 protein. Vaccine (2010) 28:3990-6. doi:10.1016/j.vaccine.2010.03.021

154. Polewicz M, Gracia A, Garlapati S, Van Kessel J, Strom S, Halperin SA, et al. Novel vaccine formulations against pertussis offer earlier onset of immunity and provide protection in the presence of maternal antibodies. Vaccine (2013) 31:3148-55. doi:10.1016/j.vaccine.2013.05.008

155. Schofield FD, Tucker VM, Westbrook GR. Neonatal tetanus in New Guinea. $\mathrm{Br}$ Med J (1961) 2:785-9. doi:10.1136/bmj.2.5255.785

156. WHO. Maternal and Neonatal Tetanus (MNT) elimination [Online]. (2014). Available from: http://www.who.int/immunization/diseases/MNTE_ initiative/en/

157. Wutzler P, Schmidt-Ott R, Hoyer H, Sauerbrei A. Prevalence of influenza A and B antibodies in pregnant women and their offspring. J Clin Virol (2009) 46:161-4. doi:10.1016/j.jcv.2009.06.024

158. Rohner GB, Meier S, Bel M, Combescure C, Othenin-Girard V, Swali RA, et al. Influenza vaccination given at least 2 weeks before delivery to pregnant women facilitates transmission of seroprotective influenza-specific antibodies to the newborn. Pediatr Infect Dis J (2013) 32:1374-80. doi:10.1097/01.inf. 0000437066.40840.c4

159. Eick AA, Uyeki TM, Klimov A, Hall H, Reid R, Santosham M, et al. Maternal influenza vaccination and effect on influenza virus infection in young infants. Arch Pediatr Adolesc Med (2011) 165:104-11. doi:10.1001/ archpediatrics.2010.192

160. Zaman K, Roy E, Arifeen SE, Rahman M, Raqib R, Wilson E, et al. Effectiveness of maternal influenza immunization in mothers and infants. $N$ Engl J Med (2008) 359:1555-64. doi:10.1056/NEJMoa0708630

161. Cohen P, Scadron SJ. The effects of active immunization of the mother upon the offspring. J Pediatr (1946) 29:609-19. doi:10.1016/S0022-3476(46) 80128-8

162. Gall SA, Myers J, Pichichero M. Maternal immunization with tetanusdiphtheria-pertussis vaccine: effect on maternal and neonatal serum antibody levels. Am J Obstet Gynecol (2011) 204(334):e331-5. doi:10.1016/j.ajog.2010. 11.024

163. Leuridan E, Hens N, Peeters N, De Witte L, Van Der Meeren O, Van Damme P. Effect of a prepregnancy pertussis booster dose on maternal antibody titers in young infants. Pediatr Infect Dis J (2011) 30:608-10. doi:10.1097/INF ob013e3182093814

164. Westra TA, De Vries R, Tamminga JJ, Sauboin CJ, Postma MJ. Cost-effectiveness analysis of various pertussis vaccination strategies primarily aimed at protecting infants in the Netherlands. Clin Ther (2010) 32:1479-95. doi:10.1016/j. clinthera.2010.07.017

165. Lopes CR, Berezin EN, Ching TH, Canuto Jde S, Costa VO, Klering EM. Ineffectiveness for infants of immunization of mothers with pneumococcal capsular polysaccharide vaccine during pregnancy. Braz J Infect Dis (2009) 13: 104-6.

166. Michaux JL, Heremans JF, Hitzig WH. Immunoglobulin levels in cord-blood serum of negroes and caucasians. Trop Geogr Med (1966) 18:10-4.

167. Saji F, Koyama M, Matsuzaki N. Current topic: human placental Fc receptors. Placenta (1994) 15:453-66. doi:10.1016/S0143-4004(05)80415-1

168. Saji F, Samejima Y, Kamiura S, Koyama M. Dynamics of immunoglobulins at the feto-maternal interface. Rev Reprod (1999) 4:81-9. doi:10.1530/ror.0. 0040081

169. Malek A, Sager R, Kuhn P, Nicolaides KH, Schneider H. Evolution of maternofetal transport of immunoglobulins during human pregnancy. Am J Reprod Immunol (1996) 36:248-55. doi:10.1111/j.1600-0897.1996.tb00172.x 
170. Healy CM, Rench MA, Baker CJ. Importance of timing of maternal combined tetanus, diphtheria, and acellular pertussis (Tdap) immunization and protection of young infants. Clin Infect Dis (2013) 56:539-44. doi:10.1093/cid/cis923

171. Cavalcante RS, Kopelman BI, Costa-Carvalho BT. Placental transfer of Haemophilus influenzae type b antibodies in malnourished pregnant women. Braz J Infect Dis (2008) 12:47-51. doi:10.1590/S1413-86702008000100011

172. Doroudchi M, Samsami Dehaghani A, Emad K, Ghaderi A. Placental transfer of rubella-specific IgG in fullterm and preterm newborns. Int J Gynaecol Obstet (2003) 81:157-62. doi:10.1016/S0020-7292(02)00442-3

173. Elliot AJ, Fleming DM. Influenza and respiratory syncytial virus in the elderly. Expert Rev Vaccines (2008) 7:249-58. doi:10.1586/14760584.7.2.249

174. Nair H, Nokes DJ, Gessner BD, Dherani M, Madhi SA, Singleton RJ, et al. Global burden of acute lower respiratory infections due to respiratory syncytial virus in young children: a systematic review and meta-analysis. Lancet (2010) 375:1545-55. doi:10.1016/S0140-6736(10)60206-1

175. Roca A, Abacassamo F, Loscertales MP, Quinto L, Gomez-Olive X, Fenwick F, et al. Prevalence of respiratory syncytial virus IgG antibodies in infants living in a rural area of Mozambique. J Med Virol (2002) 67:616-23. doi:10.1002/jmv.10148

176. Kaaijk P, Luytjes W, Rots NY. Vaccination against RSV: is maternal vaccination a good alternative to other approaches? Hum Vaccin Immunother (2013) 9:1263-7. doi:10.4161/hv.24096

177. Johnson S, Oliver C, Prince GA, Hemming VG, Pfarr DS, Wang SC, et al. Development of a humanized monoclonal antibody (MEDI-493) with potent in vitro and in vivo activity against respiratory syncytial virus. $J$ Infect Dis (1997) 176:1215-24. doi:10.1086/514115

178. Wu H, Pfarr DS, Tang Y, An LL, Patel NK, Watkins JD, et al. Ultra-potent antibodies against respiratory syncytial virus: effects of binding kinetics and binding valence on viral neutralization. J Mol Biol (2005) 350:126-44. doi:10.1016/j.jmb.2005.04.049

179. Widjojoatmodjo MN, Boes J, Van Bers M, Van Remmerden Y, Roholl PJ, Luytjes W. A highly attenuated recombinant human respiratory syncytial virus lacking the $G$ protein induces long-lasting protection in cotton rats. Virol J (2010) 7:114. doi:10.1186/1743-422X-7-114
180. McLellan JS, Chen M, Joyce MG, Sastry M, Stewart-Jones GB, Yang Y, et al. Structure-based design of a fusion glycoprotein vaccine for respiratory syncytial virus. Science (2013) 342:592-8. doi:10.1126/science.1243283

181. McLellan JS, Chen M, Leung S, Graepel KW, Du X, Yang Y, et al. Structure of RSV fusion glycoprotein trimer bound to a prefusion-specific neutralizing antibody. Science (2013) 340:1113-7. doi:10.1126/science.1234914

182. Corti D, Bianchi S, Vanzetta F, Minola A, Perez L, Agatic G, et al. Crossneutralization of four paramyxoviruses by a human monoclonal antibody. Nature (2013) 501:439-43. doi:10.1038/nature12442

183. Murphy BR, Alling DW, Snyder MH, Walsh EE, Prince GA, Chanock RM, et al. Effect of age and preexisting antibody on serum antibody response of infants and children to the $\mathrm{F}$ and $\mathrm{G}$ glycoproteins during respiratory syncytial virus infection. J Clin Microbiol (1986) 24:894-8.

184. Shinoff JJ, O’brien KL, Thumar B, Shaw JB, Reid R, Hua W, et al. Young infants can develop protective levels of neutralizing antibody after infection with respiratory syncytial virus. J Infect Dis (2008) 198:1007-15. doi:10.1086/591460

Conflict of Interest Statement: The author declares that the research was conducted in the absence of any commercial or financial relationships that could be construed as a potential conflict of interest.

Received: 28 May 2014; accepted: 01 September 2014; published online: 16 September 2014

Citation: Niewiesk S (2014) Maternal antibodies: clinical significance, mechanism of interference with immune responses, and possible vaccination strategies. Front. Immunol. 5:446. doi: 10.3389/fimmu.2014.00446

This article was submitted to Immunotherapies and Vaccines, a section of the journal Frontiers in Immunology.

Copyright (C) 2014 Niewiesk. This is an open-access article distributed under the terms of the Creative Commons Attribution License (CC BY). The use, distribution or reproduction in other forums is permitted, provided the original author(s) or licensor are credited and that the original publication in this journal is cited, in accordance with accepted academic practice. No use, distribution or reproduction is permitted which does not comply with these terms. 